Prepared in cooperation with the Village of Ruidoso, New Mexico

\title{
Geomorphic Survey of North Fork Eagle Creek, New Mexico, 2018
}

Open-File Report 2020-1121 



\section{Geomorphic Survey of North Fork Eagle Creek, New Mexico, 2018}

By Alexander P. Graziano

Prepared in cooperation with the Village of Ruidoso, New Mexico

Open-File Report 2020-1121 


\title{
U.S. Department of the Interior \\ DAVID BERNHARDT, Secretary
}

\author{
U.S. Geological Survey \\ James F. Reilly II, Director
}

U.S. Geological Survey, Reston, Virginia: 2020

For more information on the USGS - the Federal source for science about the Earth, its natural and living resources, natural hazards, and the environment—visit https://www.usgs.gov or call 1-888-ASK-USGS.

For an overview of USGS information products, including maps, imagery, and publications, visit https://store.usgs.gov/.

Any use of trade, firm, or product names is for descriptive purposes only and does not imply endorsement by the U.S. Government.

Although this information product, for the most part, is in the public domain, it also may contain copyrighted materials as noted in the text. Permission to reproduce copyrighted items must be secured from the copyright owner.

Suggested citation:

Graziano, A.P., 2020, Geomorphic survey of North Fork Eagle Creek, New Mexico, 2018: U.S. Geological Survey Open-File Report 2020-1121, 37 p., https://doi.org/10.3133/ofr20201121.

Associated data for this publication:

Graziano, A.P., 2020, Data supporting the 2018 geomorphic survey of North Fork Eagle Creek, New Mexico: U.S.

Geological Survey data release, https://doi.org/10.5066/P94ZQHKU.

ISSN 2331-1258 (online) 


\section{Contents}

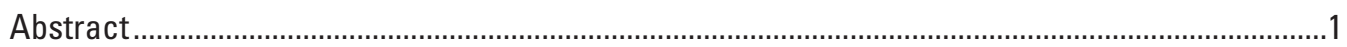

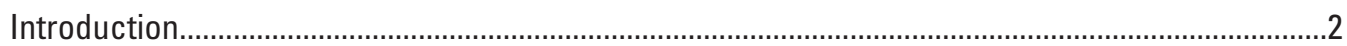

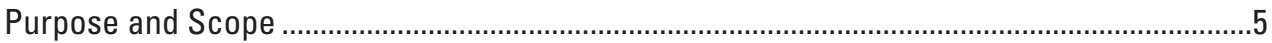

Study Area

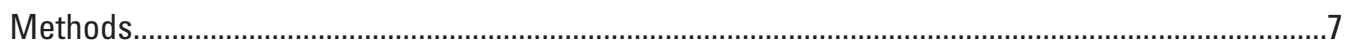

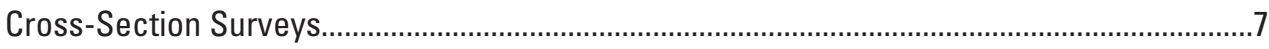

Cross-Section Plots and Characteristics.................................................................................

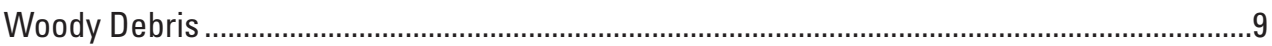

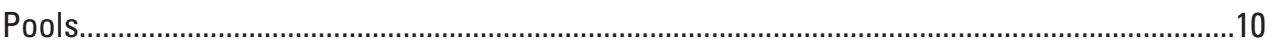

Other Features of Geomorphic Signific ance ..........................................................................11

Considerations in the Comparison of the 2017 and 2018 Survey Results ...............................12

Streamflow in the Period Between the 2017 and 2018 Surveys.....................................................12

Geomorphic Survey of North Fork Eagle Creek in 2018...........................................................15

Channel Profile

Cross-Section Plots and Characteristics........................................................................

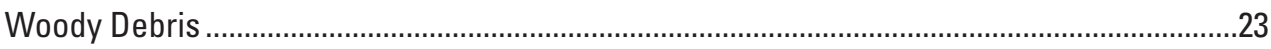

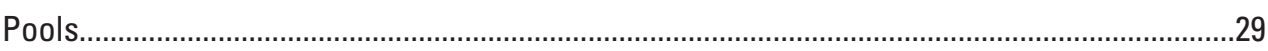

Other Features of Geomorphic Significance.......................................................................32

The Geomorphic Implications of the Hydrologic Responses to the 2012 Little Bear Fire and the Potential for Future Geomorphic Change to North Fork Eagle Creek .....................33

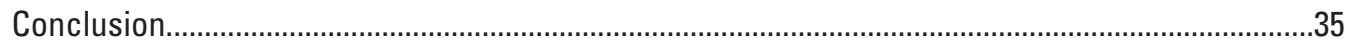

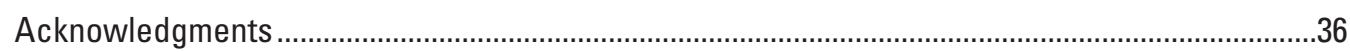

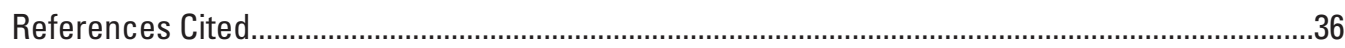

\section{Figures}

1. Map showing location of study area and geographic features in south-central New Mexico

2. Map showing location of study reach, North and South Fork Eagle Creek Basins, Eagle Creek Basin contributing area, Lincoln National Forest boundaries, streamflow-gaging stations, and wells in the study area of the Eagle Creek Basin, south-central New Mexico

3. Map showing Little Bear Fire burn severity in the North Fork Eagle Creek Basin, south-central New Mexico, as established by the Burned Area Emergency Response (BAER) Team, June 18, 2012

4. Map showing study reach with locations of streamflow-gaging stations, locations and extents of cross sections, and locations of other features in the Eagle Creek Basin, south-central New Mexico, 2018

5. Graphs showing daily mean streamflow and select peak instantaneous streamflows at the three streamflow-gaging stations in the Eagle Creek Basin, south-central New Mexico, June 19, 2017, to June 14, 2018.

6. Graph showing channel profile from cross section $1(\mathrm{X} 1)$ to cross section 14 (X14) of North Fork Eagle Creek, south-central New Mexico, 2017 and 2018 
7. Graphs showing cross sections from the 2017 and 2018 surveys plotted with 2018 estimates of bankfull stage for North Fork Eagle Creek, south-central New Mexico

8. Maps showing study reach with locations of woody debris accumulations and pools relative to the locations of cross sections, streamflow-gaging stations, and other features in the Eagle Creek Basin, south-central New Mexico, 2018

9. Photographs showing examples of woody debris accumulations identified in North Fork Eagle Creek, south-central New Mexico, 2018...

10. Photographs showing examples of pools found in North Fork Eagle Creek, south-central New Mexico, 2018.

11. Photographs showing examples of channel bifurcations and fine-sediment accumulations found in North Fork Eagle Creek, south-central New Mexico, 2018.......33

\section{Tables}

1. Streamflow-gaging stations in the study area of the Eagle Creek Basin, south-central New Mexico

2. Channel-profile data from cross sections of North Fork Eagle Creek, south-central New Mexico, 2017 and 2018

3. Cross-section characteristics of North Fork Eagle Creek, south-central New Mexico, 2018.

4. Locations, classifications, and average rates of woody debris accumulations in the study reach, Eagle Creek Basin, south-central New Mexico, 2018

5. Locations, residual depth classifications, dry or wet indications, and average rates of pools in the study reach, Eagle Creek Basin, south-central New

Mexico, 2018. 


\section{Conversion Factors}

U.S. customary units to International System of Units

\begin{tabular}{|c|c|c|}
\hline Multiply & By & To obtain \\
\hline \multicolumn{3}{|c|}{ Length } \\
\hline inch (in.) & 2.54 & centimeter $(\mathrm{cm})$ \\
\hline inch (in.) & 25.4 & millimeter (mm) \\
\hline foot $(\mathrm{ft})$ & 0.3048 & meter $(\mathrm{m})$ \\
\hline mile (mi) & 1.609 & kilometer $(\mathrm{km})$ \\
\hline \multicolumn{3}{|c|}{ Area } \\
\hline acre & 4,047 & square meter $\left(\mathrm{m}^{2}\right)$ \\
\hline acre & 0.4047 & hectare (ha) \\
\hline acre & 0.4047 & square hectometer $\left(\mathrm{hm}^{2}\right)$ \\
\hline acre & 0.004047 & square kilometer $\left(\mathrm{km}^{2}\right)$ \\
\hline square foot $\left(\mathrm{ft}^{2}\right)$ & 929.0 & square centimeter $\left(\mathrm{cm}^{2}\right)$ \\
\hline square foot $\left(\mathrm{ft}^{2}\right)$ & 0.09290 & square meter $\left(\mathrm{m}^{2}\right)$ \\
\hline square mile $\left(\mathrm{mi}^{2}\right)$ & 259.0 & hectare (ha) \\
\hline square mile $\left(\mathrm{mi}^{2}\right)$ & 2.590 & square kilometer $\left(\mathrm{km}^{2}\right)$ \\
\hline \multicolumn{3}{|c|}{ Flow rate } \\
\hline cubic foot per second $\left(\mathrm{ft}^{3} / \mathrm{s}\right)$ & 0.02832 & cubic meter per second $\left(\mathrm{m}^{3} / \mathrm{s}\right)$ \\
\hline \multicolumn{3}{|c|}{ Hydraulic gradient } \\
\hline foot per mile (ft/mi) & 0.1894 & meter per kilometer $(\mathrm{m} / \mathrm{km})$ \\
\hline
\end{tabular}

\section{Datum}

Vertical coordinate information is referenced to the North American Vertical Datum of 1988 (NAVD 88), except in some cases to the National Geodetic Vertical Datum of 1929 (NGVD 29).

Horizontal coordinate information is referenced to the North American Datum of 1983 (NAD 83).

\section{Abbreviations}

LWD large woody debris

RTK GNSS real-time kinematic global navigation satellite system

SAC slope-area computation

SACGUI slope-area computation graphical user interface

USDA U.S. Department of Agriculture

USGS U.S. Geological Survey 



\title{
Geomorphic Survey of North Fork Eagle Creek, New Mexico, 2018
}

\author{
By Alexander P. Graziano
}

\section{Abstract}

About one-quarter of the water supply for the Village of Ruidoso, New Mexico, is from groundwater pumped from wells located along North Fork Eagle Creek in the National Forest System lands of the Lincoln National Forest near Alto, New Mexico. Because of concerns regarding the effects of groundwater pumping on surface-water hydrology in the North Fork Eagle Creek Basin and the effects of the 2012 Little Bear Fire, which resulted in substantial loss of vegetation in the basin, the U.S. Department of Agriculture Forest Service, Lincoln National Forest, has required monitoring of a portion of North Fork Eagle Creek for short-term geomorphic change as part of the permitting decision that allows for the continued pumping of the production wells. The objective of this study is to address the geomorphic monitoring requirements of the permitting decision by conducting annual geomorphic surveys of North Fork Eagle Creek along the stream reach between the North Fork Eagle Creek near Alto, New Mexico, streamflow-gaging station (U.S. Geological Survey [USGS] site 08387550) and the Eagle Creek below South Fork near Alto, New Mexico, streamflow-gaging station (USGS site 08387600 ). The monitoring of short-term geomorphic change in the stream reach began in June 2017 with surveys of select cross sections and surveys of all woody debris accumulations and pools found in the channel. In June 2018, the monitoring of short-term geomorphic change continued with another geomorphic survey of the stream reach (with some modification to the monitoring methods).

The 2017 and 2018 surveys were conducted by the USGS, in cooperation with the Village of Ruidoso, and were the first two in a planned series of five annual geomorphic surveys. The results of the 2017 geomorphic survey were summarized and interpreted in a previous USGS Open-File Report, and the data were published in the companion data release of that report. In this report, the results of the 2018 geomorphic survey are summarized, interpreted, and compared to the results of the 2017 survey. The data from the 2018 geomorphic survey are published in the companion data release of this report.

The study reach surveyed in June 2018 is 1.89 miles long, beginning about 260 feet upstream from the North Fork Eagle Creek near Alto, New Mexico, streamflow-gaging station and ending at the Eagle Creek below South Fork near Alto, New Mexico, streamflow-gaging station. Large sections of the study reach are characterized by intermittent streamflow, and where streamflow is normally continuous (including at the upper and lower portions of the study reach, near the streamflow-gaging stations), the streamflow typically remains less than 2 cubic feet per second throughout the year except during seasonal high flows, which most often result from rainfall during the North American monsoon months of July, August, and September or from snowmelt runoff in March, April, and May. Between the 2017 and 2018 surveys, high-flow events resulting from both rainfall (during the North American monsoon season) and snowmelt runoff (during the winter) occurred in the study reach, and those high-flow events appeared to have caused some minor and localized geomorphic changes in the study reach, which were evaluated through comparison of the 2017 and 2018 survey results.

For the 2017 geomorphic survey of North Fork Eagle Creek, cross sections were established and surveyed at 14 locations along the study reach, and in 2018, those same 14 cross sections were resurveyed. Comparisons of the cross-section survey results indicated that minor observable geomorphic changes had occurred in 3 of the 14 cross sections. These minor observable geomorphic changes included aggradation or degradation of surface materials by about 1-2 feet in some parts of the affected cross sections.

To further assess geomorphic changes within the study reach, other features, including woody debris accumulations and pools, were surveyed in both 2017 and 2018. During the 2018 geomorphic survey, 112 distinct accumulations of woody debris and 71 pools were identified in the study reach. Charred wood or burn-marked wood was present in at least 17 of the identified woody debris accumulations (and was present in some of the woody debris accumulations identified during the 2017 survey), indicating that some of the woody debris in the channel may have been sourced from trees or forest litter that had burned during 2012 Little Bear Fire. Only 22 of the 112 woody debris accumulations identified during the 2018 survey were certain to have also been present during the 2017 survey (when 58 woody debris accumulations were identified), indicating that most of the woody debris accumulations surveyed in 2017 were likely transported during the high-flow events between the 2017 and 2018 surveys but also indicating that the flows during those events were not high enough to 
remove some of the more firmly anchored woody debris accumulations. Most woody debris accumulations identified in 2018 did not appear to have substantially influenced geomorphic change in the locations where they were found. However, the formation of 10 of the 71 pools identified in the study reach in 2018 appeared to have been influenced by the presence of woody debris, indicating that some woody debris accumulations may have driven local geomorphic changes. Notably, pool totals from the 2017 survey could not be accurately compared to the pool totals from the 2018 survey because of differences between the two surveys in the methods used to identify pools.

Because the study began 5 years after the 2012 Little Bear Fire, and because the period and geomorphic scope of the study have so far been limited, it cannot be said that the geomorphic changes observed between the 2017 and 2018 surveys are representative of a pattern of geomorphic change following the 2012 Little Bear Fire. Though, once geomorphic changes between the 2017 and 2018 surveys can be compared with results from geomorphic surveys planned for 2019, 2020, and 2021, it may be possible to develop an understanding of the patterns in geomorphic change following the 2012 Little Bear Fire.

\section{Introduction}

Water supply for the Village of Ruidoso, New Mexico, is derived from surface-water and groundwater resources of the Eagle Creek and Rio Ruidoso Basins (U.S. Department of Agriculture [USDA] Forest Service, 2015), which are both located within the Upper Rio Hondo Basin in south-central New Mexico (fig. 1). On average, 24-29 percent of the annual water supply for the village is derived from three active (of four in total) municipal production wells (hereafter referred to as "North Fork wells") located along North Fork Eagle Creek in the National Forest System lands of the Lincoln National Forest near Alto, New Mexico (USDA Forest Service, 2016) (fig. 2). The North Fork Eagle Creek Basin is one of two basins (the other is the South Fork Eagle Creek Basin) that make up nearly all of the 8.1 square mile $\left(\mathrm{mi}^{2}\right)$ portion of the Eagle Creek Basin located upstream from the U.S. Geological Survey (USGS) streamflow-gaging station Eagle Creek below South Fork near Alto, New Mexico (USGS site 08387600; hereafter referred to as the "Eagle Creek gaging station") (fig. 2).

The North Fork wells began production in 1988, and the special use permit for operation of the wells (granted by the USDA Forest Service, Lincoln National Forest) expired in 1995 (USDA Forest Service, 2015). At that time, discussions began regarding the renewal of the special use permit (USDA Forest Service, 2015). A concern by some parties was the potential effect of well operations on streamflow in Eagle
Creek (USDA Forest Service, 2015). As a result of these concerns, the USGS, in cooperation with the Village of Ruidoso, conducted a study of North Fork Eagle Creek from 2007 to 2009 to characterize the hydrology of the Eagle Creek Basin upstream from the Eagle Creek gaging station and the effects of groundwater pumping on streamflow (Matherne and others, 2010).

Following the USGS study, the USDA Forest Service, Lincoln National Forest, issued the "North Fork Eagle Creek Wells Special Use Authorization Project Draft Environmental Impact Statement" in May 2012, shortly before the start of the Little Bear Fire, which, in June 2012, burned approximately 3,380 acres of the 3,400-acre North Fork Eagle Creek Basin (USDA Forest Service, 2015) (fig. 3). Burn severities in the basin ranged from high to very low or unburned. Specifically, 26 percent of the basin burned at high severity, 26 percent burned at moderate severity, 27 percent burned at low severity, and 21 percent either burned at very low severity or remained unburned (USDA Forest Service, 2015) (fig. 3). Notably, the North Fork Eagle Creek riparian corridor (defined as the area extending 200 feet [ft] out on either side of the channel) primarily burned at or below low severity, and there was little loss of vegetation in this area (USDA Forest Service, 2015).

Following the Little Bear Fire, changes in some aspects of the hydrology of North Fork Eagle Creek were expected, including reduced infiltration and increased overland runoff, temporary increases in "flashy" responses to rainfall and snowmelt, increased sediment and debris yields, and changes to vegetation as a result of flooding (USDA Forest Service, 2016). On the basis of the altered postwildfire watershed conditions, a supplemental draft environmental impact statement was released by the USDA Forest Service, Lincoln National Forest, in 2014 (USDA Forest Service, 2015). In February 2016, the USDA Forest Service, Lincoln National Forest, released the "Record of Decision, North Fork Eagle Creek Wells Special Use Authorization," which established new monitoring and mitigation requirements but allowed the Village of Ruidoso to continue to operate the North Fork wells (USDA Forest Service, 2016).

The "Record of Decision, North Fork Eagle Creek Wells Special Use Authorization" established the one alternative, among those considered in the final environmental impact statement, that was to be implemented (USDA Forest Service, 2016). It also stipulated the terms and conditions of a new special use permit. Included in the decision were multiple monitoring measures designed to help determine direct or indirect effects of pumping on the quantity and quality of both surface water and groundwater. The Village of Ruidoso entered into a cooperative agreement with the USGS for assistance in one of these monitoring efforts, which involves periodic geomorphic surveys of a portion of North Fork Eagle Creek. 


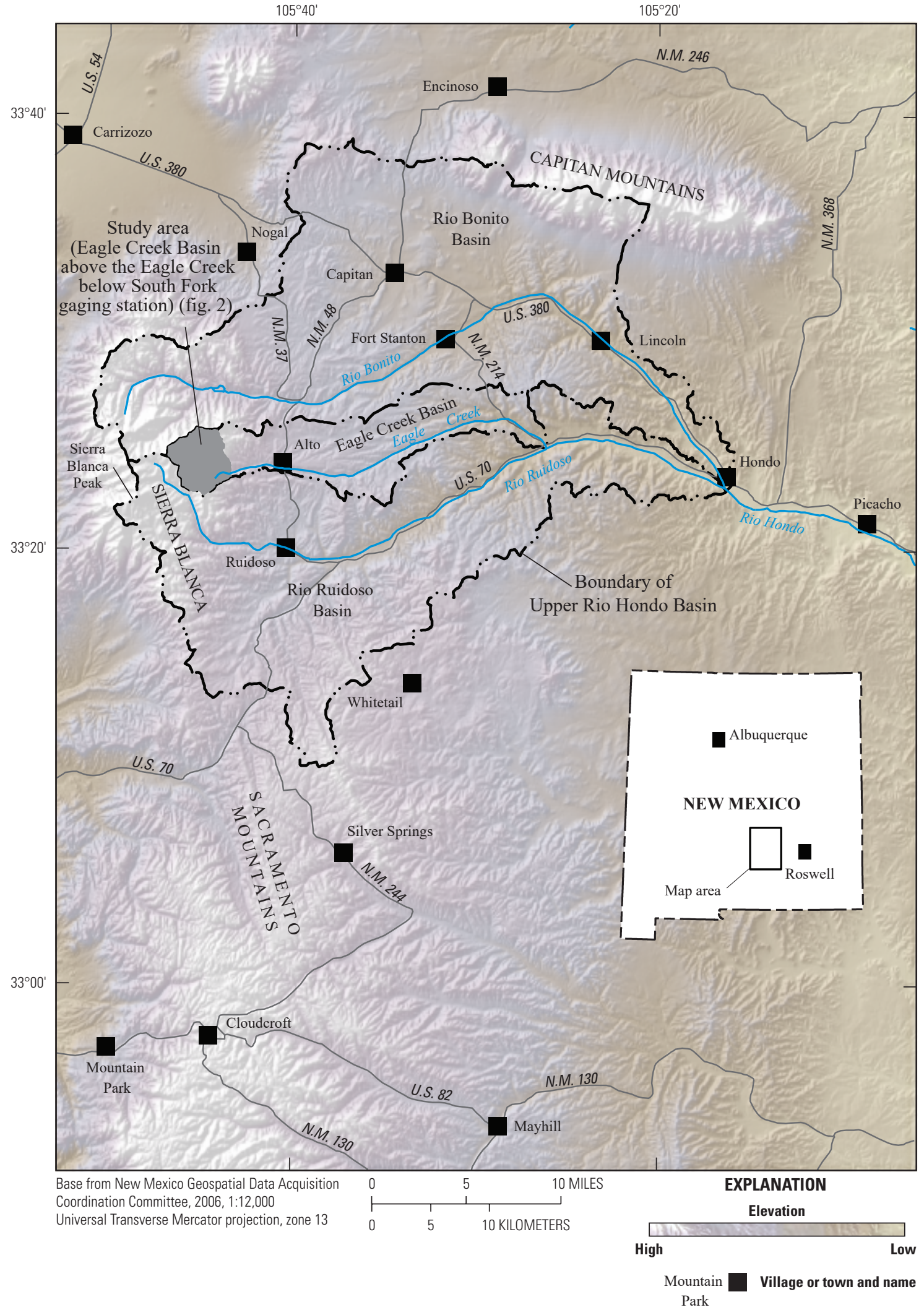

Figure 1. Location of study area and geographic features in south-central New Mexico (modified from Matherne and others, 2010). 


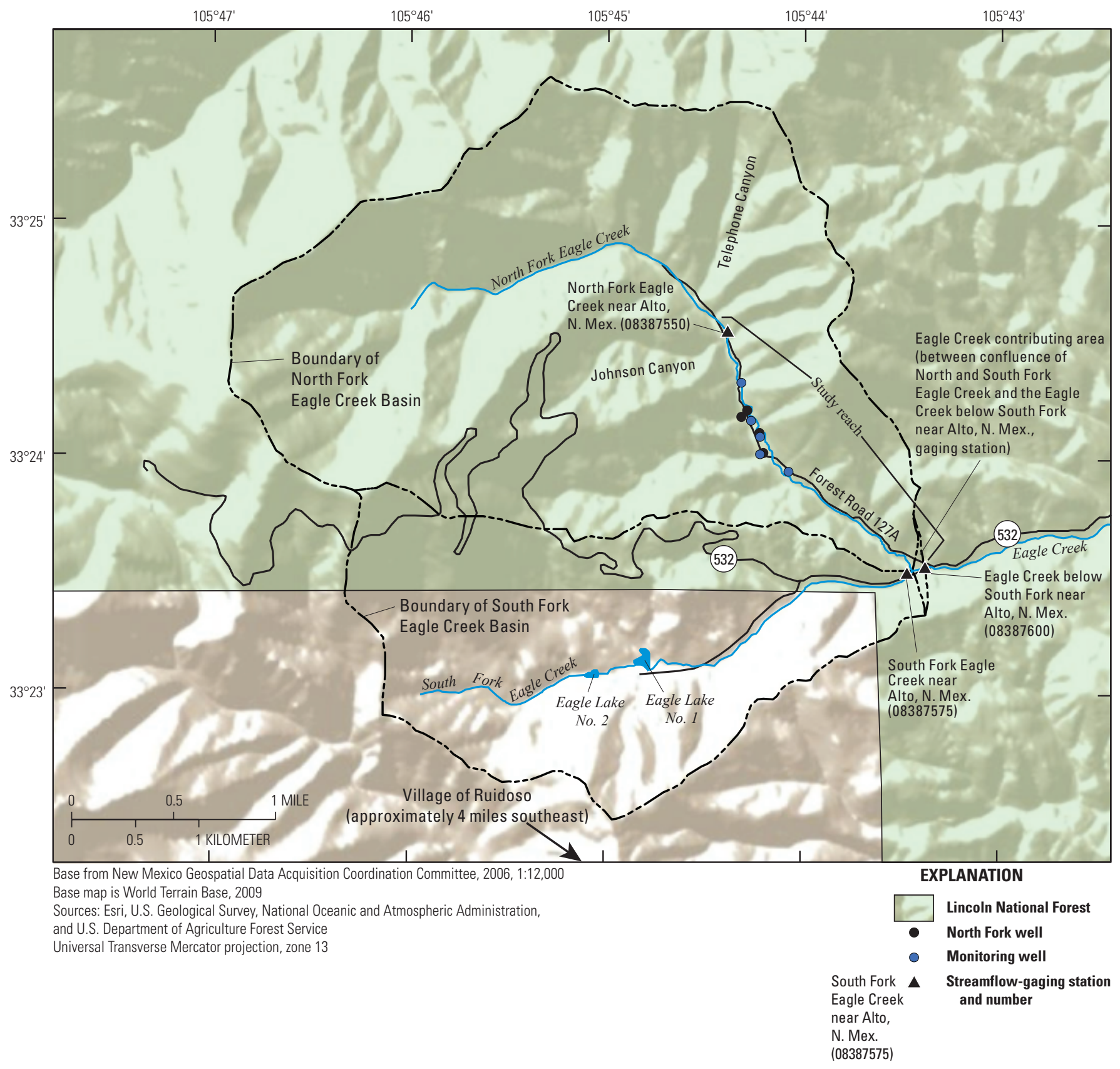

Figure 2. Location of study reach, North and South Fork Eagle Creek Basins, Eagle Creek Basin contributing area, Lincoln National Forest boundaries, streamflow-gaging stations, and wells in the study area of the Eagle Creek Basin, south-central New Mexico (modified from Matherne and others, 2010).

The objective of this study is to address the geomorphic monitoring requirements of the USDA Forest Service record of decision (USDA Forest Service, 2016) by conducting annual geomorphic surveys of North Fork Eagle Creek along the stream reach between the North Fork Eagle Creek near Alto, New Mexico, streamflow-gaging station (USGS site 08387550; hereafter referred to as the "North Fork gaging station") and the Eagle Creek gaging station (fig. 2). Specific plans for this study include conducting annual geomorphic surveys for 5 years (from 2017 to 2021), publishing all quality-assured survey data in a series of data releases, and publishing annual reports that summarize the surveyed geomorphic characteristics of the reach and changes from previous surveys. 


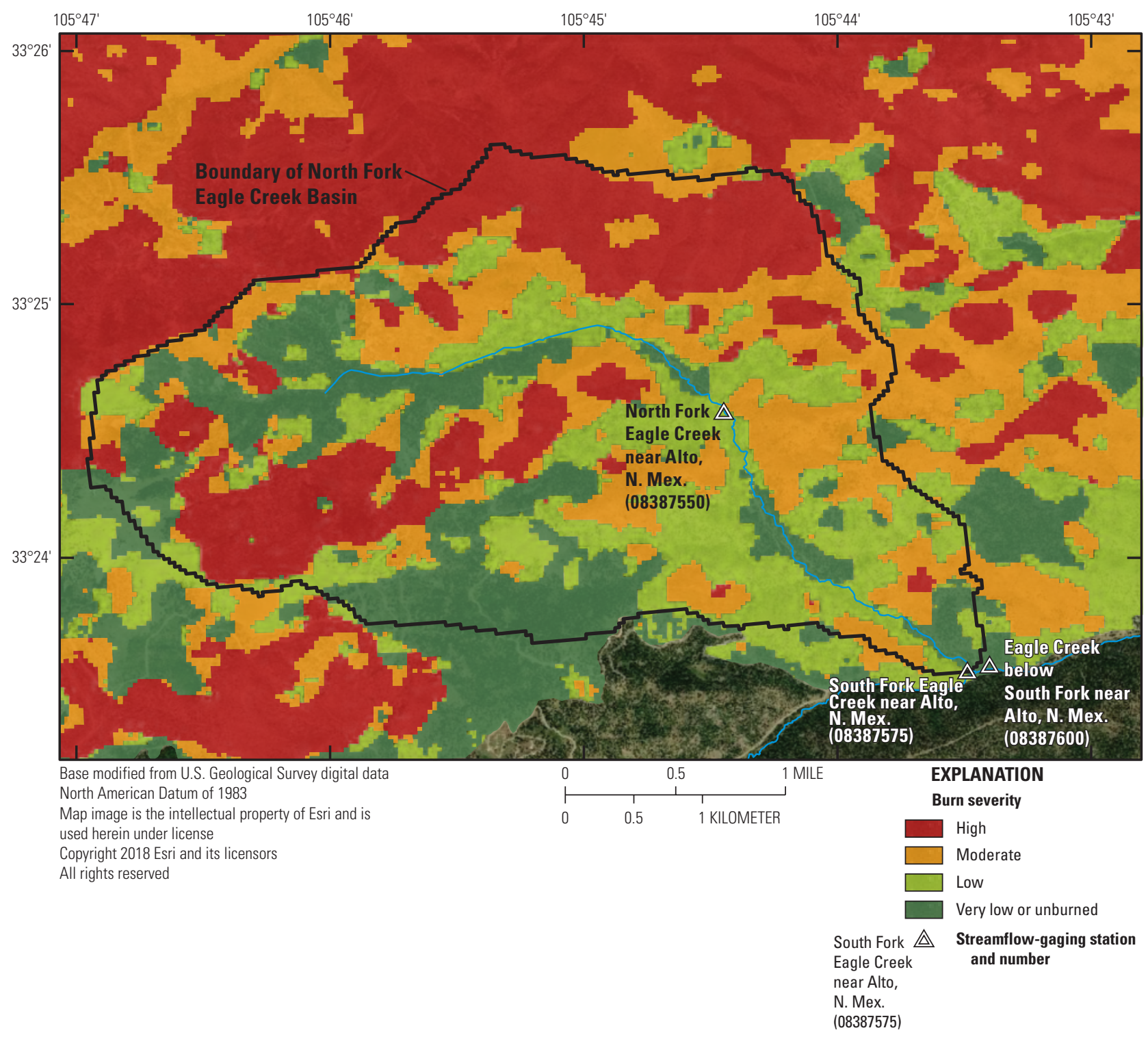

Figure 3. Little Bear Fire burn severity in the North Fork Eagle Creek Basin, south-central New Mexico, as established by the Burned Area Emergency Response (BAER) Team, June 18, 2012. Modified from data published in U.S. Department of Agriculture (USDA) Forest Service, Little Bear Fire BAER Team (2012).

\section{Purpose and Scope}

The purpose of this report is to present the results from the 2018 geomorphic survey of North Fork Eagle Creek. The 2018 geomorphic survey, which is the second of the five planned surveys, is summarized, interpreted, and compared to the results of the 2017 survey (the first of the five planned surveys). The survey data used for this report are published in Graziano (2020), the companion data release of this report. In Graziano (2019), the results from the 2017 geomorphic survey are summarized and interpreted, and the survey data used for that report are published in Graziano (2018).

\section{Study Area}

The study area is the portion of the Eagle Creek Basin located upstream from the Eagle Creek gaging station (area of $8.1 \mathrm{mi}^{2}$ ) (fig. 1 and fig. 2). The study area is located on the eastern flank of the Sierra Blanca within the Upper Rio Hondo Basin, about 4 miles (mi) northwest of the Village of Ruidoso, New Mexico, and about 2.5 mi west of Alto, New Mexico (fig. 1). Included in the study area are the North Fork Eagle Creek Basin (area of $5.3 \mathrm{mi}^{2}$ ), the South Fork Eagle Creek Basin (area of $2.8 \mathrm{mi}^{2}$ ), and a small contributing area from the Eagle Creek Basin (area of less than $0.1 \mathrm{mi}^{2}$ ) (fig. 2). The study area is a forested mountain watershed where the dominant tree species are Pinus ponderosa (ponderosa pine) and mixed conifers (Matherne and others, 2010). 
Surface-water streamflow in the study area is measured by the USGS at three streamflow-gaging stations (fig. 2; table 1). These streamflow-gaging stations include the previously mentioned North Fork and Eagle Creek gaging stations in addition to the South Fork Eagle Creek near Alto, New Mexico, streamflow-gaging station (USGS site 08387575; hereafter referred to as the "South Fork gaging station"). The Eagle Creek gaging station is located $270 \mathrm{ft}$ $(0.05 \mathrm{mi})$ downstream from the confluence of North Fork Eagle Creek and South Fork Eagle Creek, 1.84 mi downstream from the North Fork gaging station, and $430 \mathrm{ft}(0.08 \mathrm{mi})$ downstream from the South Fork gaging station (fig. 2). The North Fork gaging station is located 1.79 mi upstream from the confluence of North Fork Eagle Creek and South Fork Eagle Creek (fig. 2), and the South Fork gaging station is located $160 \mathrm{ft}(0.03 \mathrm{mi})$ upstream from the confluence of North Fork Eagle Creek and South Fork Eagle Creek (fig. 2).

The focus of the study is the North Fork Eagle Creek Basin, which was substantially burned by the 2012 Little Bear Fire (fig. 3). It is a mostly undeveloped basin, with exceptions including the wells and their associated infrastructure and a group of 22 cabins, which are mostly located upstream from the North Fork gaging station (Matherne and others, 2010). The basin is defined by narrow, steep drainages. The head of drainage for North Fork Eagle Creek has an elevation of about $10,500 \mathrm{ft}$, whereas $4.5 \mathrm{mi}$ downstream, the Eagle Creek gaging station (270 ft downstream from the mouth of North Fork Eagle Creek) has an elevation of about 7,600 ft, giving North Fork Eagle Creek an average stream gradient of about 640 feet per mile (ft/mi) (Matherne and others, 2010).

The study reach begins about $260 \mathrm{ft}$ upstream from the North Fork gaging station (where there is a bridge that carries Forest Road 127A over North Fork Eagle Creek) and ends at the Eagle Creek gaging station, which is $270 \mathrm{ft}$ below the confluence of North Fork Eagle Creek and South Fork Eagle Creek (fig. 2). In total, the study reach is $1.89 \mathrm{mi}$ long, which is about $160 \mathrm{ft}$ longer than the study reach defined for the 2017 survey (the study reach for the 2017 survey began about $100 \mathrm{ft}$ upstream from the North Fork gaging station [Graziano, 2019] instead of $260 \mathrm{ft}$ upstream from the North Fork gaging station).
Large sections of the study reach are characterized by intermittent streamflow, and streamflow levels in the study reach have likely been affected by the North Fork wells that pump groundwater from the bedrock aquifer to supply water to the Village of Ruidoso (Matherne and others, 2010). Specifically, Matherne and others (2010) estimated that, for an 11-year period before the North Fork wells were drilled (from 1970 to 1980), groundwater flow out of the basin represented about 33 percent of basin yield, and for a 13-year period after the North Fork wells were put into service (from 1988 to 2000), groundwater flow out of the basin represented about 16 percent of basin yield and mean annual groundwater pumping represented about 17 percent of basin yield. Additionally, Matherne and others (2010) approximated that, beginning about $1,600 \mathrm{ft}(0.3 \mathrm{mi})$ downstream from the North Fork gaging station, the streambed has the capacity to transmit water into the bedrock aquifer at a rate of about $0.7-1$ cubic foot per second $(\mathrm{ft} 3 / \mathrm{s})$; therefore, if it is assumed that the bedrock aquifer would be saturated if groundwater pumping had never occurred, then water being transmitted to the aquifer would instead be flowing continuously or saturating the alluvium. However, Matherne and others (2010) concluded that streamflow in some part of the stream channel between the North Fork and Eagle Creek gaging stations was likely intermittent during parts of both a 10 -year period before the North Fork wells were drilled (from 1970 to 1979) and a 20-year period after they were drilled (from 1989 to 2008) on the basis of alluvium and channel configurations and the available streamflow records.

Matherne and others (2010) also found that the sum of streamflows recorded at the South Fork and North Fork gaging stations was greater than the streamflow recorded at the Eagle Creek gaging station at most times during the 19-month period of record from September 2007 through March 2009. If streamflow were not lost to aquifer or alluvium infiltration in the reach of North Fork Eagle Creek located below the North Fork gaging station, it would be expected that the sum of the streamflows recorded at the South Fork and North Fork gaging stations would always be less than or equal to the streamflow at the Eagle Creek gaging station.

Table 1. Streamflow-gaging stations in the study area of the Eagle Creek Basin, south-central New Mexico.

[mi², square mile; NGVD 29, National Geodetic Vertical Datum of 1929]

\begin{tabular}{lcccc}
\hline \multicolumn{1}{c}{ Site name } & Site number & Period of record & $\begin{array}{c}\text { Drainage area } \\
\text { (mi2) }\end{array}$ & $\begin{array}{c}\text { Elevation } \\
\text { (feet above NGVD 29) }\end{array}$ \\
\hline Eagle Creek below South Fork near Alto, New Mexico & 08387600 & $\begin{array}{c}1969-80 ; \\
1988-\text { present }\end{array}$ & 8.14 & 7,600 \\
\hline North Fork Eagle Creek near Alto, New Mexico & 08387550 & $2007-$ present & 3.16 & 7,900 \\
\hline South Fork Eagle Creek near Alto, New Mexico & 08387575 & 2007 -present & 2.79 \\
\hline
\end{tabular}




\section{Methods}

The field survey was conducted during June 12-14, 2018, when continuous streamflow (recorded at 15-minute intervals) at the North Fork gaging station ranged from 0.11 to $0.18 \mathrm{ft} 3 / \mathrm{s}$ (U.S. Geological Survey, 2019b), there was no streamflow at the Eagle Creek gaging station (U.S. Geological Survey, 2019a), and the lower $1.45 \mathrm{mi}$ of the $1.89 \mathrm{mi}$ study reach was observed to be dry at the surface at the time it was surveyed. During the 2018 field survey, the 14 cross-section locations established in 2017 (Graziano, 2019) (fig. 4) were resurveyed by using USGS techniques and methods for single-base real-time kinematic global navigation satellite system (RTK GNSS) surveys (Rydlund and Densmore, 2012). All accumulations of woody debris, all pools, and all other features of geomorphic significance found in the reach were identified, cataloged, photographed, and surveyed for location (by using RTK GNSS receivers or estimation methods). All accumulations of woody debris were classified by their potential to form debris jams, all pools were measured for residual depth, and select pools were surveyed for thalweg elevation by using RTK GNSS receivers.

\section{Cross-Section Surveys}

In 2017, cross sections were surveyed at 14 locations along the study reach of North Fork Eagle Creek (Graziano, 2019) (fig. 4). The cross-section locations were initially chosen on the basis of equal distance estimations, with one cross section established approximately every $1,500 \mathrm{ft}$, beginning $100 \mathrm{ft}$ upstream from the North Fork gaging station and ending $380 \mathrm{ft}$ upstream from the confluence with South Fork Eagle Creek (Graziano, 2019). Additional cross sections were then established in 2017 at locations that were thought to be particularly susceptible to geomorphic change. These additional cross sections were established directly downstream from tributaries and road crossings and in the middle of large flood deposits (which were identified as sections of the study reach where floodplain vegetation was sparse and floodplain surface materials were primarily composed of coarse, unconsolidated sediments that appeared to have been transported and deposited during recent seasonal high-flow events).

At the 14 locations where cross sections were established and surveyed in 2017, reference marks for future surveys were monumented in concrete on both banks (Graziano, 2019). In 2018, those reference marks were used to identify and resurvey the same 14 cross sections (fig. 4). Cross sections were surveyed from the left to the right from the perspective looking downstream and included points within the channel and on the adjacent floodplains. Cross sections were surveyed in accordance with USGS standard protocols (Benson and Dalrymple, 1967), whereby individual surveyed points were selected on the basis of where substantial changes in slope occurred. Selected survey points also included the points of lowest elevation in each cross section.
Individual cross-section points were surveyed for location and elevation by using USGS techniques and methods for single-base RTK GNSS surveys as described in Rydlund and Densmore (2012). One base station position was used to correct all cross-section points to the same horizontal and vertical datums, but because insufficient positional data were collected with the base station receiver, the accuracy of the points, relative to the North American Datum of 1983 (NAD 83) and the North American Vertical Datum of 1988 (NAVD 88), could not be determined; therefore, all cross-section points have approximate local horizontal and vertical positional accuracies ranging from plus or minus $( \pm) 0.1$ to $\pm 0.2 \mathrm{ft}$ (with a few exceptions noted in Graziano [2020]), but their positional accuracies relative to NAD 83 and NAVD 88 are unknown.

\section{Cross-Section Plots and Characteristics}

Cross-section plots were developed by using the slope-area computation graphical user interface (SACGUI) application (Bradley, 2012). SACGUI utilizes version 7 of the slope-area computation (SAC) program, which is described in Fulford (1994). SAC was developed on the basis of the standard USGS slope-area measurement technique presented in Dalrymple and Benson (1967) and is regularly used within the USGS. SACGUI includes a method for the development of cross-section plots by using $x-y-z$ coordinates. For this study, SACGUI was used to convert $\mathrm{x}-\mathrm{y}$ coordinates to "distance from left bank" values, which represent the distance from the left reference mark. Additionally, on the basis of bankfull stage estimates, other cross-section characteristics (including channel width and area and bank heights and slopes) were either calculated in SACGUI or were derived from SACGUI output files.

Bankfull stage is the water level of the bankfull streamflow, which has been defined as the streamflow that completely fills the channel without spilling onto the floodplain (Leopold and others, 1964; Knighton, 1998). Estimates of bankfull stage were largely based on field observations of bank locations but were also informed by the cross-section plots, the photographs of the cross sections, and the bankfull stage estimates that were made for the 2017 survey (Graziano, 2019). The primary topographic features used to determine bankfull stage were the abrupt decreases in slope typically associated with the transition between the channel and the floodplain. These determinations were then secondarily verified by changes in terrain and vegetation. However, because the point at which there was a transition between the channel and the floodplain was poorly defined in some areas, making good estimates of bankfull stage was difficult for some cross-section locations. Additionally, determination of bankfull stage is characteristically subjective (Johnson and Heil, 1996). Therefore, to retain consistency in the methods used to determine bankfull stage, two criteria adapted from those established in Graziano (2019) were also used for estimating bankfull stage in 2018 at North Fork Eagle Creek. 


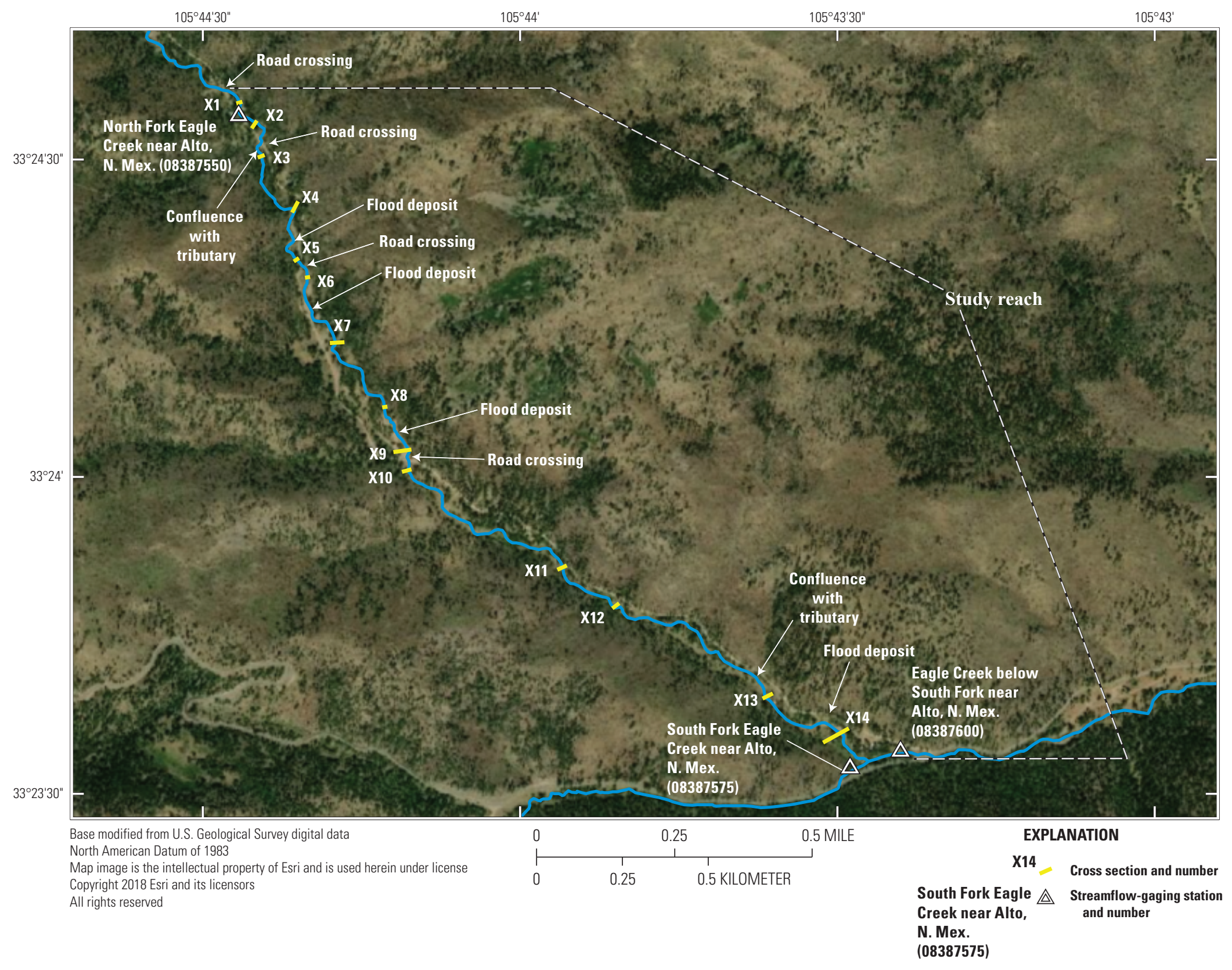

Figure 4. Study reach with locations of streamflow-gaging stations, locations and extents of cross sections, and locations of other features in the Eagle Creek Basin, south-central New Mexico, 2018. 
First, because the tops of the left and right banks were never at the exact same elevation, but they were often close enough that either could be reasonably used for estimating bankfull stage, it was decided that estimates of bankfull stage should always be based directly on the elevation of the lower of the two banks. Second, at the locations where banks were well defined, the channel often appeared to be between 1 and $3 \mathrm{ft}$ deep; therefore, it was decided that, for locations where banks were poorly defined, any decreases in slope between the depths of about 1 and $3 \mathrm{ft}$ would be carefully considered when making estimates of bankfull stage. In Graziano (2019, p. 9), a third criterion established for making estimates of bankfull stage stated, "if it was found that the initial choice for bankfull stage was at a stage which could hypothetically result in water flowing or pooling in a smaller side channel, then to reduce uncertainty in channel characteristic determinations, bankfull stage was lowered to a stage just below the base of the smaller side channel, where, at that stage, it could be assumed that flow would only be occurring in the main channel." This criterion was not followed when bankfull stage was established during the 2018 survey because there were some well-defined banks of the main channel that were at elevations above the deepest points of the side channels, and using this criterion would result in inaccurate estimates of bankfull stage in those areas. Where these side channels were present, the cross-section characteristics discussed in the next paragraph were calculated on the basis of the main channel alone.

Estimates of bankfull stage were then used to calculate the following cross-section characteristics for each cross section: maximum depth at bankfull stage (in feet), cross-section width (in feet), cross-section area (in square feet), left and right bank heights (in feet), and left and right bank slopes (dimensionless, in feet per foot). Maximum depth at bankfull stage was defined as the depth of the thalweg at bankfull stage. Cross-section width was defined as the width of the water surface of the main channel at bankfull stage. Cross-section area was defined as the wetted area of the main channel at bankfull stage. Left and right bank heights were defined as the heights of the two banks of the main channel at bankfull stage, and left and right bank slopes were defined as the slopes of the two banks of the main channel at bankfull stage. Maximum depths at bankfull stage, cross-section areas, and cross-section widths were calculated in SACGUI. Bank heights and slopes were calculated on the basis of field observations and interpretations of SACGUI results. Specifically, bank heights and slopes were calculated by defining top of bank as the point at which bankfull stage intersected with the left or right bank and by defining bottom of bank as the cross-section point at the base of the corresponding left or right bank. Cross-section points that represented the bases of banks were primarily identified in the field and were typically found to be points at the edges of the channel where abrupt increases in slope began.

\section{Woody Debris}

Woody debris is an important component of forested watersheds that can substantially affect the hydrology, geomorphology, and ecology of streams (Wallace and others, 1995; Abbe and Montgomery, 1996; Gurnell and others, 2002). Geomorphic studies of woody debris often focus on large woody debris (LWD), typically defined as logs and branches greater than $0.3 \mathrm{ft}$ in diameter and $5 \mathrm{ft}$ in length (Heimann, 2017), a definition that is also used for LWD in this report. Importantly, LWD can serve as "key members" of debris jams (Abbe and Montgomery, 1996), meaning that they can initiate the formation of debris jams. Debris jams can control pool and bar formation (Abbe and Montgomery, 1996), pool spacing (Montgomery and others, 1995), and sediment storage, channel width, and stream gradient (Nakamura and Swanson, 1993), in addition to other geomorphic channel characteristics (Gurnell and others, 2002).

During the 2018 survey, all areas where woody debris accumulated in the channel of the study reach of North Fork Eagle Creek were identified, cataloged, photographed, and surveyed for location (using generally the same methods that were used for the 2017 survey [Graziano, 2019] but with more rigorous application). Woody debris was identified by walking the study reach of the channel from upstream to downstream. Generally, areas with woody debris of any size were cataloged and referred to as "woody debris accumulations," including individually scattered pieces of LWD and small piles of twigs and sticks. However, individually scattered twigs and sticks were not cataloged, photographed, or surveyed for location, as this type of debris mostly looked to have fallen directly into the channel from nearby trees instead of being deposited by streamflow. Additionally, the potential geomorphic effects of this type of debris were presumed to be insignificant.

Woody debris accumulations were surveyed for location mostly by using the same RTK GNSS methods that were used to survey the cross-section points. However, many woody debris accumulations were found in places where RTK GNSS reception was poor; therefore, the locations of woody debris accumulations determined by using RTK GNSS receivers have approximate local horizontal positional accuracies ranging from \pm 0.1 to $\pm 3.0 \mathrm{ft}$ and unknown horizontal positional accuracies relative to NAD 83. Additionally, because of various considerations (such as RTK GNSS reception issues), the precise points surveyed for woody debris accumulations were not consistent (that is, some woody debris accumulations were surveyed near their centers, and others were surveyed closer to one of their edges). For woody debris accumulations where location was not determined by using RTK GNSS receivers, the locations were estimated by using field notes (which included estimated distances between all features), photographs, and digital mapping software (specifically, Google Earth). The horizontal positional accuracies of locations determined by using this method were estimated to be $\pm 50 \mathrm{ft}$. This accuracy estimate was largely based on how well the estimated distances between features surveyed using 
RTK GNSS (from the field notes) compared with the actual distances between those features (from the RTK GNSS survey results). In Graziano (2020), the location source (either RTK GNSS or digital map) is included for each surveyed point.

From the photographs, all identified woody debris accumulations were later classified on the basis of whether they were debris deposits, potential debris jams, or active debris jams. These classifications were originally defined in Graziano (2019) for the 2017 survey. For the 2018 survey, the definitions remained the same and are given in the next three paragraphs (with some modifications to their wordings).

Debris deposits are defined as areas containing pieces of woody debris that appear to have been deposited in a largely random fashion on the recessions of wood-mobilizing streamflows (Graziano, 2019). Debris deposits could be found anywhere in the channel and could include scattered LWD or loose accumulations of smaller woody debris. Because debris deposits were not identified as active or potential debris jams (which are defined in the next two paragraphs), they were not characterized by debris packed together tightly, and they did not appear to contain debris-jam key members that could potentially initiate the formation of a jam (particularly, not in the location where they were found). Further, the LWD of debris deposits containing LWD often looked to barely meet the size limit for LWD ( $0.3 \mathrm{ft}$ diameter and $5 \mathrm{ft}$ long), and they did not typically retain any limbs; therefore, the likelihood that this type of debris could later snag, or anchor, and thereby form a key member of a debris jam was presumed to be low. Pieces from debris deposits could, however, later add to the volume of debris jams farther downstream.

Potential debris jams are defined as areas containing pieces of LWD that have the potential to later serve as key members in debris jams (Graziano, 2019). The LWD found in potential debris jams could be trees that fell from the adjacent floodplain or hillslope into or across the channel (and may still be anchored to the bank), logs that were placed across the channel by people (for recreational purposes), or logs that were carried downstream by high flows (which settled perpendicular or oblique to flow direction and were long enough to span most, if not all, of the channel in their settled locations). The likelihood that the LWD found in these areas could become key members in debris jams, particularly in the areas where they were found, was presumed to be higher than that of the woody debris accumulations defined as debris deposits.

Active debris jams are defined as areas where woody debris jams have already formed (Graziano, 2019). They were identified by the presence of woody debris and possibly other debris (including grass, pinecones, pine needles, and sediment) packed tightly against one or more key members of woody debris. Further, the tightly packed debris was usually observed to be on the upstream side of the key members. The key members were typically LWD, but because of the relatively small size of the channel in some locations, they could be smaller than the LWD definition used for this study. Because woody debris jams can control geomorphic channel characteristics, active debris jams were presumed to be the most likely woody debris accumulations that had served or could later serve as drivers of geomorphic change in the study reach.

\section{Pools}

Pools, which are important components of stream ecosystems, provide habitat for various aquatic species (Wallace and others, 1995) and contribute to hydraulic complexity, which supports habitat diversity (Buffington and others, 2002). Pool dimensions and frequency can be affected by woody debris (Montgomery and others, 1995; Abbe and Montgomery, 1996), sediment load (Madej and Ozaki, 1996), and other watershed disturbances (Lisle, 1982).

During the 2018 survey, all pools in the main channel of the study reach of North Fork Eagle Creek were identified, cataloged, photographed, surveyed for location, and measured for residual depth. Additionally, the deepest parts of select pools (where RTK GNSS reception was good) were surveyed for thalweg elevation. In wet sections of the study reach, pools were identified as locations at base flow where velocities decreased and water depths increased. They were verified by the presence of downstream riffle crests or artificial weirs, which were at higher elevations than the channel thalweg and controlled the stage. In dry sections of the study reach, pools were primarily identified as locations where the thalweg of the channel appeared to be longitudinally concave and, in the presence of water, would presumably adopt the features previously mentioned.

Pools were surveyed for location by using the same methods that were used for the woody debris accumulations. The locations of pools determined by using RTK GNSS receivers have approximate local horizontal positional accuracies ranging from \pm 0.1 to $\pm 3.0 \mathrm{ft}$ and unknown horizontal positional accuracies relative to NAD 83 . Additionally, because of various considerations (such as RTK GNSS reception issues), the precise points surveyed for pools were mostly inconsistent (that is, some pools were surveyed at the location of their deepest point, but others were surveyed closer to one of their edges). The locations of pools determined by using field notes, photographs, and digital mapping software have horizontal positional accuracies estimated to be $\pm 50 \mathrm{ft}$. Like with the woody debris accumulations, this accuracy estimate was largely based on how well the estimated distances between features surveyed by using RTK GNSS (from the field notes) compared with the actual distances between those features (from the RTK GNSS survey results). For the select pools where thalweg elevations were also surveyed and published, the approximate local horizontal and vertical positional accuracies range from \pm 0.1 to $\pm 0.2 \mathrm{ft}$, and the horizontal and vertical positional accuracies relative to NAD 83 and NAVD 88 were unknown. In Graziano (2020), the location source (either RTK GNSS or digital map) is included for each surveyed point. 
During the 2018 survey, pools were measured for residual depth (these measurements are also planned for the future surveys but were not made during the 2017 survey). Residual depth is the difference in depth or bed elevation between a pool and the downstream riffle crest (Lisle, 1987). Residual depth is a simple, unbiased, and ecologically important pool dimension that is independent of variations caused by streamflow (Lisle, 1987) and is therefore a good metric for monitoring geomorphic change to pools over time.

For measuring residual depth at pools identified in wet sections of the study reach, an engineer's rule was used to measure water depth at both the deepest part of each pool and the deepest part of each pool's downstream riffle crest. Residual depth for each pool was calculated by taking the difference between the two values. Using this method, residual depths were measured to the nearest $0.01 \mathrm{ft}$, and on the basis of uncertainty in the correct selection of the deepest parts of the pools and riffle crests, accuracy was estimated to be $\pm 0.1 \mathrm{ft}$.

For measuring residual depth at pools identified in dry sections of the study reach, a survey rod with engineer's scale was held vertically at the deepest part of each dry pool, and the height of the lowest point of each dry pool's downstream riffle crest was roughly measured by line of sight. The height determined for each dry pool's downstream riffle crest was the residual depth. Using this method, the residual depths were measured to the nearest $0.5 \mathrm{ft}$, and the accuracy was estimated to be $\pm 0.5 \mathrm{ft}$, which means that dry pools with residual depths at $0.5 \mathrm{ft}$ were within the level of detection but may not actually function as pools during periods when water is present. The large uncertainty in the residual depths of dry pools reflects the difficulty in both the identification of pools and the measuring of the residual depths of pools in dry sections of the study reach. Graziano (2020) includes indications of whether water was present or absent at each pool at the time it was surveyed.

On the basis of the residual depth results from the 2018 survey and of the accuracy of the dry pool measurements, residual depth classifications were developed for all pools in the study reach. All pools with residual depths less than $0.75 \mathrm{ft}$ were classified as shallow, all pools with residual depths between 0.75 and $1.25 \mathrm{ft}$ were classified as intermediate, and all pools with residual depths greater than $1.25 \mathrm{ft}$ were classified as deep.

\section{Other Features of Geomorphic Significance}

Beginning with the 2018 survey, other features of geomorphic significance (including road crossings, flood deposits, tributary confluences, channel bifurcations, and fine-sediment accumulations) found in the study reach of North Fork Eagle Creek were identified, cataloged, photographed, and surveyed for location. Road crossings were identified as locations where the study reach crosses Forest Road 127A (fig. 2) by flowing under a bridge or through a culvert or as locations where the study reach crosses Forest Road 127A by flowing over it (that is, locations where vehicles on the Forest Road 127A are required to ford the stream channel to cross it). Flood deposits were identified as sections of the study reach where floodplain vegetation was sparse and floodplain surface materials were primarily composed of coarse, unconsolidated sediments that appeared to have been transported and deposited during recent seasonal high-flow events. The larger flood deposits were also associated with braiding of the channel. Tributary confluences were identified by either flowing water seen entering the study reach during the survey or by the presence of culverts seen along the road adjacent to the study reach. Channel bifurcations were identified as areas where the main channel forked into two different directions before converging again within about $100 \mathrm{ft}$ (for each channel bifurcation, the points of both forking and reconvergence were identified and surveyed). Areas where the channel appeared to separate into more than two distributaries were not identified as channel bifurcations. Fine-sediment accumulations were identified as fine-grained deposits (finer than those in the surrounding streambed) that were impounded by obstructions in the main channel (for example, woody debris accumulations, boulders, and bedrock).

Notably, the methods for identifying tributary confluences, channel bifurcations, and fine-sediment accumulations were not rigorously adhered to during the 2018 survey; therefore, the catalog of these features was not comprehensive for the study reach. However, because at least some of these features were photographed and surveyed, the information that was collected for them can be used for future spot monitoring of geomorphic change to the study reach. For example, the photographs taken of these features during the 2018 survey and those planned to be taken during future surveys may provide evidence of qualitative changes. Regarding fine-sediment accumulations specifically, if the fine-sediment accumulations or other identifiable features (such as the colocated active debris jams) remain in place, the photographs taken during the 2018 survey and those planned to be taken during future surveys may provide evidence of change, either to the stability or the dimensions of the fine-sediment accumulations. Some quantitative changes can also be monitored. For example, regarding channel bifurcations, changes to the channel length of the identified channel bifurcations can be monitored because points both where the channel forked and where the channel reconverged were surveyed.

Road crossings and flood deposits were first identified in the field and then located by using aerial imagery from March 2016 in Google Earth. Because the locations of road crossings and flood deposits were defined as points and could be verified by characteristics that were visible in aerial imagery (for example, in aerial imagery, flood deposits could be identified by a lack of vegetation and by sand-colored surface material extending out $25 \mathrm{ft}$ or more from the sides of the channel), horizontal positional accuracy for those features was not determined because it would not have exceeded the relatively large size of the features. For the remaining other features of geomorphic significance, the locations were determined by using either RTK GNSS receivers or the estimation methods used for woody debris accumulations and pools. Therefore, the locations of other 
features of geomorphic significance that were determined by using RTK GNSS receivers have approximate local horizontal positional accuracies ranging from \pm 0.1 to $\pm 3.0 \mathrm{ft}$ and unknown horizontal positional accuracies relative to NAD 83. The locations of other features of geomorphic significance that were determined by using field notes, photographs, and digital mapping software have estimated horizontal positional accuracies of $\pm 50 \mathrm{ft}$. In Graziano (2020), the location source (either RTK GNSS or digital map) is included for each surveyed point.

\section{Considerations in the Comparison of the 2017 and 2018 Survey Results}

To compare the results of the 2017 and 2018 geomorphic surveys of North Fork Eagle Creek, certain datum discrepancies between the two datasets needed to be accounted for. The datum discrepancies included relatively small, but quantifiable and correctable, horizontal datum differences between the 2017 and 2018 surveys (ranging from about 0 to $3 \mathrm{ft}$ ) and relatively large, but quantifiable and correctable, vertical datum differences (ranging from about 5 to $8 \mathrm{ft}$ ) between the 2017 and 2018 surveys. The datum discrepancies resulted from poor horizontal and vertical positional accuracies of the survey data relative to NAD 83 and NAVD 88 in both 2017 and 2018. The datum discrepancies were correctable because the reference marks surveyed in both years at each cross section did not appear to move and because the approximate local horizontal and vertical positional accuracies of cross-section data from both years were of mostly good quality ( \pm 0.1 to $\pm 0.2 \mathrm{ft}$ ).

To account for these datum discrepancies, the locations and elevations for all of the 2017 survey cross-section data used for comparison in this report (including those cross-section data that were used for comparing channel profiles from the two surveys) were corrected to the local horizontal and vertical datums of the 2018 survey on a cross-section by cross-section basis. The datum corrections were done by, first, determining the differences between the 2017 and 2018 cross-section reference mark locations and elevations; second, averaging the location and elevation differences from each cross section's left and right bank reference marks; and third, using those average differences to individually transform the location and elevation data from each 2017 cross section to the horizontal and vertical datums of the 2018 survey. Further, uncertainty for each datum correction was calculated by comparing the location and elevation differences from each cross section's left and right bank reference marks (that is, uncertainty for each datum correction was calculated as the difference between the values that were averaged together in the second step).

Other sources of uncertainty in cross-section data comparisons included the RTK GNSS accuracies (discussed in the earlier "Cross-Section Surveys" section) and the roughness of the topography. Features that contributed to the roughness of the topography included coarse surface materials, such as rocks and vegetation. Field measurements that could be used to calculate uncertainty from the roughness of the topography have not been made; therefore, uncertainties in 2017 and 2018 cross-section data comparisons were not able to be completely and accurately quantified. However, these sources of uncertainty were considered and are discussed in the comparison of the channel-profile and cross-section results from the 2017 and 2018 surveys.

Other discrepancies that were considered when comparing the results of the 2017 and 2018 surveys included possible differences in the application of the methods used for identifying woody debris accumulations and known differences in the methods used for identifying pools. These discrepancies were also sources of uncertainty that were considered and are discussed in the comparisons of the woody debris accumulation and pool survey results from 2017 and 2018. Generally, photographic evidence needed to be heavily relied on for these comparisons.

\section{Streamflow in the Period Between the 2017 and 2018 Surveys}

In this section, the streamflow records that are presented and discussed are primarily those for the period between the 2017 and 2018 geomorphic surveys. Streamflow records from before the 2017 geomorphic survey were presented and discussed in Graziano (2019). Generally, Graziano (2019) found that, for the period of record ending in 2017, streamflow at the streamflow-gaging stations in the Eagle Creek Basin most often remained less than $2.00 \mathrm{ft} 3 / \mathrm{s}$, with any sustained periods of streamflow greater than $2.00 \mathrm{ft} 3 / \mathrm{s}$ typically resulting from snowmelt runoff in March, April, and May (it was approximated by Matherne and others [2010] that sustained flows greater than $2.2 \mathrm{ft} 3 / \mathrm{s}$ are needed to maintain continuous streamflow in North Fork Eagle Creek). Graziano (2019) also found that, for the period of record ending in 2017, peak annual streamflows greater than $50 \mathrm{ft} 3 / \mathrm{s}$ had about a 2-year recurrence interval at both the North Fork and Eagle Creek gaging stations, and at all three streamflow-gaging stations in the Eagle Creek Basin, when peak annual streamflows greater than $50 \mathrm{ft} 3 / \mathrm{s}$ occurred, they most often resulted from heavy rainfall occurring during the North American monsoon season of July through September.

Daily mean streamflow at the Eagle Creek gaging station for the record period starting on the first day of the 2017 survey and ending on the last day of the 2018 survey (June 19, 2017 , to June 14,2018 ) ranged from values of $0.00 \mathrm{ft} 3 / \mathrm{s}$, which occurred from May 29, 2018, to June 14, 2018, to a value of $81.5 \mathrm{ft} 3 / \mathrm{s}$, which occurred on February 17, 2018 (U.S. Geological Survey, 2019a) (fig. 5A). Daily mean streamflows were less than $2.00 \mathrm{ft} 3 / \mathrm{s}$ for 325 of the 361 days from June 19, 2017, to June 14, 2018 (U.S. Geological Survey, 2019a) (fig. $5 \mathrm{~A}$ ). Since USGS gaging at this location first began in 1969 , daily mean streamflow has mostly remained less than $2.00 \mathrm{ft} 3 / \mathrm{s}$ (Graziano, 2019). 

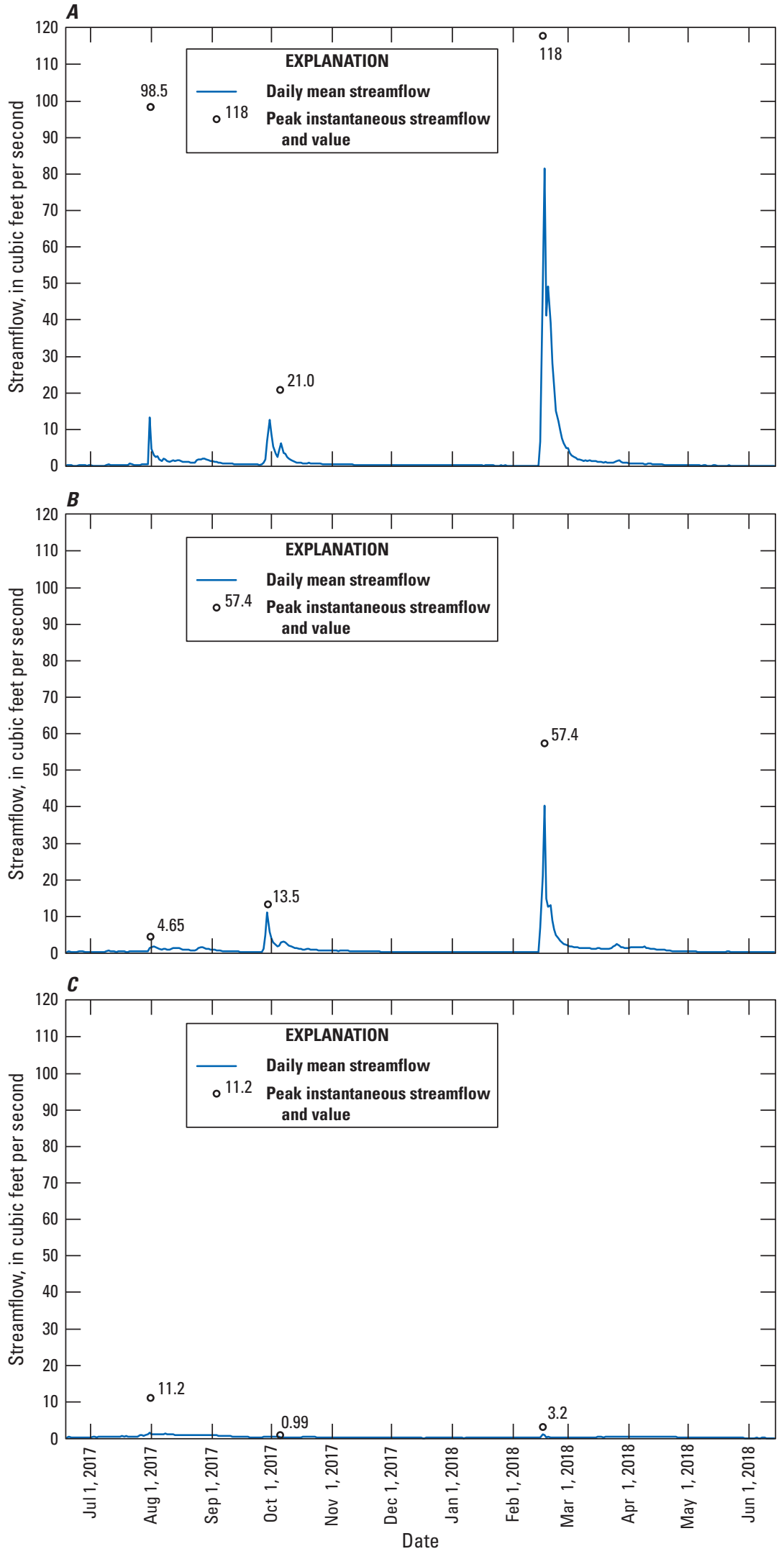

Figure 5. Daily mean streamflow and select peak instantaneous streamflows at the three streamflow-gaging stations in the Eagle Creek Basin, south-central New Mexico, June 19, 2017, to June 14, 2018. $A$, Eagle Creek below South Fork near Alto, New Mexico, streamflow-gaging station (U.S. Geological Survey [USGS] site 08387600) (U.S. Geological Survey, 2019a). B, North Fork Eagle Creek near Alto, New Mexico, streamflow-gaging station (USGS site 08387550) (U.S. Geological Survey, 2019b). C, South Fork Eagle Creek near Alto, New Mexico, streamflow-gaging station (USGS site 08387575) (U.S. Geological Survey, 2019c). 
There were two distinct high-flow events where peak instantaneous streamflow exceeded $50 \mathrm{ft} 3 / \mathrm{s}$ at the Eagle Creek gaging station during the period from June 19, 2017, to June 14, 2018. The two high-flow events had peak instantaneous streamflows of $98.5 \mathrm{ft} 3 / \mathrm{s}$ and $118 \mathrm{ft} 3 / \mathrm{s}$, which occurred on July 31, 2017, and February 16, 2018, respectively (U.S. Geological Survey, 2019a) (fig. 5A). The high-flow event that produced the peak on July 31, 2017, was distinctly flashier than the high-flow event that produced the peak on February 16, 2018. Specifically, the peak on July 31, 2017, was reached about 45 minutes after the start of its event, whereas the peak on February 16, 2018, was reached about 35 hours after the start of its event (U.S. Geological Survey, 2019a). Further, streamflow during the event that produced the peak on February 16, 2018, remained greater than $50 \mathrm{ft}^{3} / \mathrm{s}$ for about 2 days in total, whereas streamflow during the event that produced the peak on July 31,2017 , only remained greater than $50 \mathrm{ft} 3 / \mathrm{s}$ for about 2 hours (U.S. Geological Survey, 2019a).

Daily mean streamflow at the North Fork gaging station, for the record period from June 19, 2017, to June 14, 2018, ranged from values of $0.13 \mathrm{ft} 3 / \mathrm{s}$, which occurred on June 12 , 2018 , and June 13,2018 , to a value of $40.3 \mathrm{ft} 3 / \mathrm{s}$, which occurred on February 17, 2018 (the same day as the maximum daily mean streamflow at the Eagle Creek gaging station for the period from June 19, 2017, to June 14, 2018) (U.S. Geological Survey, 2019a, b) (fig. $5 A$ and $B$ ). Daily mean streamflows were less than $2.00 \mathrm{ft} 3 / \mathrm{s}$ for 332 of the 361 days from June 19, 2017, to June 14, 2018 (U.S. Geological Survey, 2019b) (fig. 5B). Since USGS gaging at this location first began in 2007 , daily mean streamflow has mostly remained less than $2.00 \mathrm{ft}^{3} / \mathrm{s}$ (Graziano, 2019), which means that streamflow between the North Fork and Eagle Creek gaging stations has likely been discontinuous at most times since 2007 (based on the approximation in Matherne and others [2010] that sustained flows greater than $2.2 \mathrm{ft} 3 / \mathrm{s}$ are needed to maintain continuous streamflow in North Fork Eagle Creek).

There was only one distinct high-flow event where peak instantaneous streamflow exceeded $50 \mathrm{ft} 3 / \mathrm{s}$ at the North Fork gaging station during the period from June 19, 2017, to June 14, 2018. The high-flow event had a peak instantaneous streamflow of $57.4 \mathrm{ft} 3 / \mathrm{s}$, which occurred on February 17, 2018 (U.S. Geological Survey, 2019b) (fig. 5B). Like the peak at the Eagle Creek gaging station on February 16, 2018 (which was only about 6 hours earlier and resulted from the same high-flow event), the peak at the North Fork gaging station on February 17, 2018, was not reached until about 2 days after the high-flow event began (U.S. Geological Survey, 2019a, b). However, unlike the streamflow during the event that produced the peak at the Eagle Creek gaging station on February 16, 2018, which remained greater than $50 \mathrm{ft} 3 / \mathrm{s}$ for about 2 days in total, the streamflow during the event that produced the peak at the North Fork gaging station on February 17, 2018, only remained greater than $50 \mathrm{ft} 3 / \mathrm{s}$ for about 6 hours in total (U.S. Geological Survey, 2019a, b). Presumably, this difference was largely caused by substantial tributary inflows into the study reach of North Fork Eagle Creek (below the North Fork gaging station) because the peak instantaneous streamflow for this event at the South Fork gaging station was only 3.2 $\mathrm{ft} 3 / \mathrm{s}$ (U.S. Geological Survey, 2019c) (fig. 5C), and that streamflow-gaging station accounts for nearly all of the water that flows to the Eagle Creek gaging station from outside of the North Fork Eagle Creek Basin (fig. 2).

Daily mean streamflow at the South Fork gaging station, for the record period from June 19, 2017, to June 14, 2018, ranged from values of $0.08 \mathrm{ft} 3 / \mathrm{s}$, which occurred on May 31, 2018 , and June 1, 2018, to a value of $1.47 \mathrm{ft} 3 / \mathrm{s}$, which occurred on July 31, 2017 (the same day as one of the peak instantaneous streamflows greater than $50 \mathrm{ft} 3 / \mathrm{s}$ at the Eagle Creek gaging station for the period from June 19, 2017, to June 14, 2018) (U.S. Geological Survey, 2019a, c) (fig. $5 A$ and $C$ ). Daily mean streamflows were less than $1.00 \mathrm{ft} 3 / \mathrm{s}$ for 346 of the 361 days from June 19, 2017, to June 14, 2018 (U.S. Geological Survey, 2019c) (fig. 5C). Since USGS gaging at this location first began in 2007, daily mean streamflow has mostly remained less than $1.00 \mathrm{ft} 3 / \mathrm{s}$ (Graziano, 2019). There were no high-flow events where peak instantaneous streamflow exceeded $50 \mathrm{ft} 3 / \mathrm{s}$ at the South Fork gaging station during the period from June 19, 2017, to June 14, 2018 (U.S. Geological Survey, 2019c) (fig. 5C).

For 329 of the 361 days from June 19, 2017, to June 14, 2018, the sums of the daily streamflows recorded at the North Fork and South Fork gaging stations were higher than the daily streamflows recorded at the Eagle Creek gaging station (U.S. Geological Survey, 2019a, b, c), and for most of those 329 days, streamflows at the streamflow-gaging stations were at their typical levels (less than $2.00 \mathrm{ft}^{3} / \mathrm{s}$ at the Eagle Creek and North Fork gaging stations and less than $1.00 \mathrm{ft} 3 / \mathrm{s}$ at the South Fork gaging station). This is evidence that, during those 329 days, substantial portions of the water flowing by the North Fork gaging station were likely being lost to aquifer recharge or alluvium saturation in the reach of North Fork Eagle Creek located below the North Fork gaging station. For the other 32 days from June 19, 2017, to June 14, 2018, the sums of the daily streamflows recorded at the North Fork and South Fork gaging stations were lower than the daily streamflows recorded at the Eagle Creek gaging station (U.S. Geological Survey, 2019a, b, c). All 32 of those days were during high-flow events (with peak instantaneous streamflows greater than $20 \mathrm{ft} 3 / \mathrm{s}$ ) recorded at the Eagle Creek gaging station (fig. $5 A$ ). Specifically, 3 of the 32 days were during the late July-early August event in 2017, 9 of the 32 days were during the late September-early October event, and 20 of the 32 days were during the mid-February-early March event (U.S. Geological Survey, 2019a, b, c). Further, at some point during each of those events, streamflows at the Eagle Creek gaging station were more than double the sums of the streamflows at the North Fork and South Fork gaging stations (U.S. Geological Survey, 2019a, b, c), indicating that, during those events, tributaries to North Fork Eagle Creek (below the North Fork gaging station) were likely contributing substantial amounts of streamflow to the study reach. 


\section{Geomorphic Survey of North Fork Eagle Creek in 2018}

The results of the 2018 geomorphic survey, presented in the following sections, have been derived from field notes, field photographs, and the companion data release (Graziano, 2020). The data release contains the full set of survey points and includes their unique identifiers (IDs), locations (as horizontal coordinates), elevations (for cross-section points and the deepest points of select pools), "distance from left bank" values (for cross-section points), classifications (for woody debris accumulations), residual depths (for pools), descriptions, and location sources. Also included are indications of whether water was present or absent at each point at the time it was surveyed. The results of the 2017 geomorphic survey, which are compared to the results of the 2018 geomorphic survey in the following sections, are published in Graziano $(2018,2019)$. Because of the horizontal and vertical datum differences discussed in the "Methods" section, those results were modified for this report where the channel-profile and cross-section results of the two years are compared.

\section{Channel Profile}

A channel profile of the study reach, from cross section 1 to cross section 14, was developed on the basis of the cross-section thalweg points surveyed in 2018 and compared to the channel profile of the study reach from 2017 (fig. 6; table 2). The 2018 survey results indicated that between cross section 1 and cross section 14 there was $269.5 \mathrm{ft}$ of fall over 9,185 $\mathrm{ft}(1.74 \mathrm{mi})$, which amounts to an average gradient of about $155 \mathrm{ft} / \mathrm{mi}$ for the study reach. Using the 2017 cross-section elevation data that have been corrected to the 2018 vertical datum, the average gradient for the study reach in 2017 was also calculated to be about $155 \mathrm{ft} / \mathrm{mi}$.

Calculations of stream gradient along the thalweg from cross section to cross section from the 2018 survey yield results that range from $127 \mathrm{ft} / \mathrm{mi}$, for both the reach segment between cross sections 11 and 12 and the reach segment between cross sections 13 and 14, to $230 \mathrm{ft} / \mathrm{mi}$, for the reach segment between cross sections 9 and 10. The gradients for all other cross-section-defined reach segments were between $143 \mathrm{ft} / \mathrm{mi}$ and $200 \mathrm{ft} / \mathrm{mi}$. Calculations of stream gradient from cross section to cross section from the 2017 survey (based on the 2017 cross-section elevation data that have been corrected to the 2018 vertical datum) yield results that range from $122 \mathrm{ft} / \mathrm{mi}$, for the reach segment between cross sections 11 and 12, to $240 \mathrm{ft} / \mathrm{mi}$, for the reach segment between cross sections 9 and 10. Excluding the two end extremes and the stream gradient for the reach segment between cross sections 13 and 14, which was $128 \mathrm{ft} / \mathrm{mi}$, the gradients for all other cross-section-defined reach segments from 2017 were between 144 and $184 \mathrm{ft} / \mathrm{mi}$. However, these differences between the stream gradient results from 2017 and 2018 may be more attributable to the coarseness of the channel bed material at the thalweg and the limited accuracies of the survey readings than to actual physical changes to the stream gradient.

\section{Cross-Section Plots and Characteristics}

Cross-section plots for the 2017 and 2018 surveys (fig. 7) (created from the cross-section data published in the Graziano [2018] and Graziano [2020] data releases), in addition to cross-section characteristics from the 2017 (Graziano, 2019) and 2018 surveys (table 3 ), indicated that channel geometries throughout the study reach varied widely in both 2017 and 2018. In 2018, maximum depth at bankfull stage ranged from 1.5 to $7.5 \mathrm{ft}$, bankfull channel width ranged from 13.6 to $94.4 \mathrm{ft}$, bankfull channel area ranged from 15.8 to 225.0 square feet, bank heights ranged from 0.7 to $7.2 \mathrm{ft}$, and bank slopes ranged from 0.1 to 2.2 (dimensionless, feet per foot) (table 3). Notably, many of the cross-section characteristics from the 2018 survey are not directly comparable to the ranges for the cross-section characteristics from the 2017 survey because for cross sections $2,3,8,9,11,12$, and 14 the bankfull stages were largely redefined for the 2018 survey, primarily on the basis of better quality bank observations rather than physical changes to the cross sections. Therefore, instead of comparing cross-section characteristics derived from bankfull stage to evaluate changes to the cross sections from 2017 to 2018 , the cross-section plots were directly compared (fig. 7).

Comparisons of the cross-section plots from 2017 and 2018 indicated that cross sections 2, 4, and 7 were the three most likely cross sections to have undergone topographic changes caused by fluvial processes (fig. $7 B, D$, and $G$ ). For all other cross sections, the changes seen in the cross-section plots were likely more attributable to the roughness of the topography and the limited accuracies of the survey readings than to physical changes to the cross-section topographies. For example, the roughness of the topography was likely the largest source of change for cross sections 12 and 14 because the channel bed at those cross sections was partially composed of boulders (some of which were greater than 1 $\mathrm{ft}$ in diameter) (fig. $7 L$ and $N$ ), and the limited accuracies of the survey readings were likely the largest sources of change for cross sections 1 and 8 because there was about $3.5 \mathrm{ft}$ of uncertainty in the horizontal datum correction used to compare the 2017 and 2018 plots of cross section 1 (fig. 7A) and about $1.1 \mathrm{ft}$ of uncertainty in the vertical datum correction used to compare the 2017 and 2018 plots of cross section 8 (fig. 7H). Notably, all other horizontal and vertical datum corrections used to compare the 2017 and 2018 cross-section plots had uncertainties of less than $1 \mathrm{ft}$. 


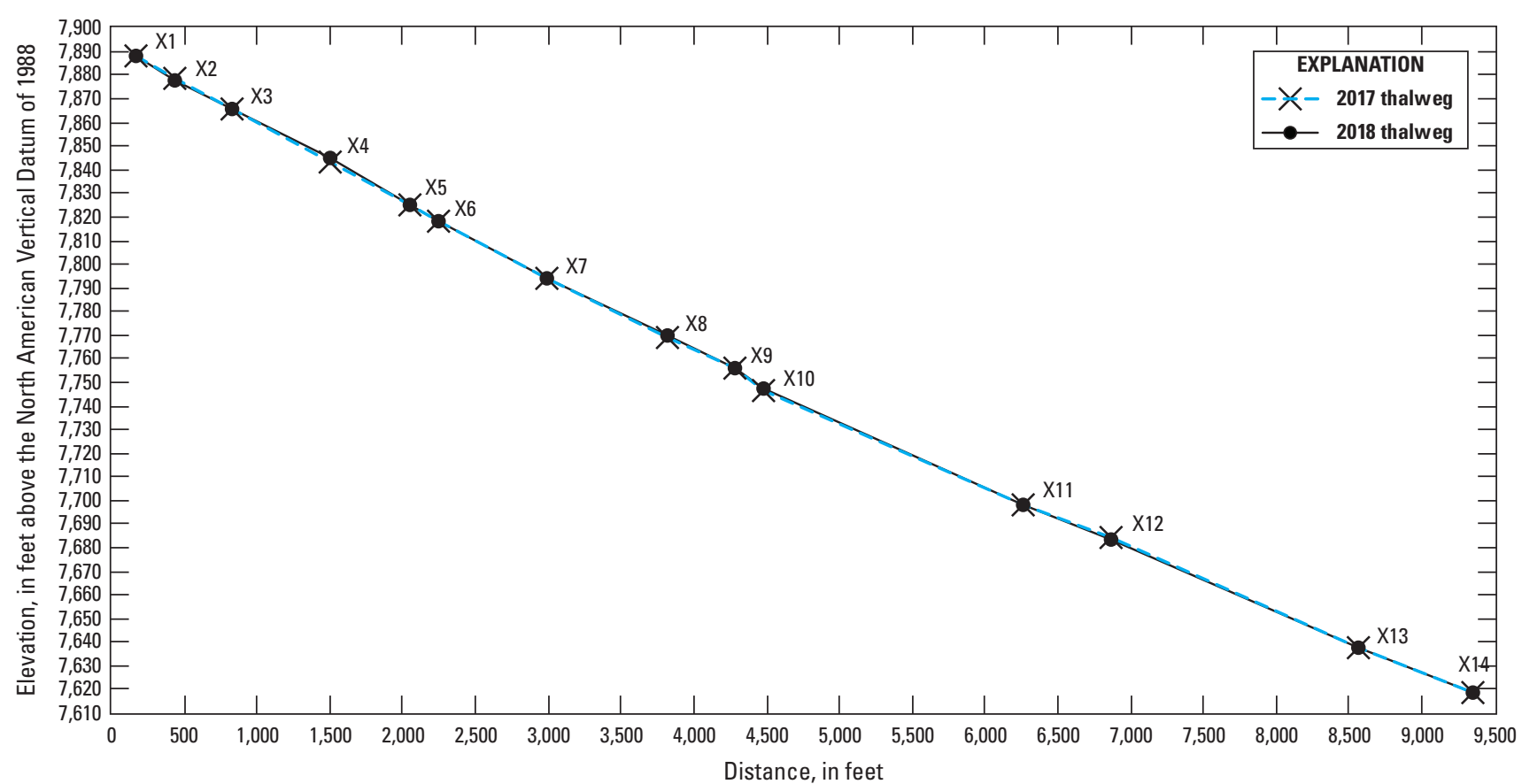

Figure 6. Channel profile from cross section 1 (X1) to cross section 14 (X14) of North Fork Eagle Creek, south-central New Mexico, 2017 and 2018. Elevations from 2017 have been corrected to the 2018 vertical datum on the basis of the differences between the 2017 and 2018 cross-section reference mark elevations.

Table 2. Channel-profile data from cross sections of North Fork Eagle Creek, south-central New Mexico, 2017 and 2018.

[Distances are based on study reach trace in figure 4 and are rounded to the nearest 5 feet; 2017 elevation data have been corrected to the 2018 vertical datum on the basis of the differences between the 2017 and 2018 cross-section reference mark elevations; stream gradients were calculated on a cross-section to cross-section basis and were assigned to the upstream cross section (for example, the stream gradient assigned to cross section 1 is for the reach between cross sections 1 and 2); ft, foot; NAVD 88, North American Vertical Datum of 1988; ft/mi, foot per mile, -, not applicable]

\begin{tabular}{llllll}
\hline $\begin{array}{c}\text { Cross section } \\
\text { number }\end{array}$ & $\begin{array}{c}\text { Distance } \\
\text { downstream } \\
\text { (ft) }\end{array}$ & $\begin{array}{c}\text { 2017 thalweg elevation } \\
\text { (ft above NAVD 88) }\end{array}$ & $\begin{array}{c}\text { 2017 stream } \\
\text { gradient } \\
\text { (ft/mi) }\end{array}$ & $\begin{array}{c}\text { 2018 thalweg elevation } \\
\text { (ft above NAVD 88) }\end{array}$ & $\begin{array}{c}\text { 2018 stream gradient } \\
\text { (ft/mi) }\end{array}$ \\
\hline 1 & 165 & $7,888.1$ & 184 & $7,888.2$ & 200 \\
2 & 440 & $7,878.5$ & 174 & $7,877.8$ & 171 \\
3 & 825 & $7,865.8$ & 176 & $7,865.3$ & 162 \\
4 & 1,495 & $7,843.5$ & 178 & $7,844.8$ & 187 \\
5 & 2,045 & $7,825.0$ & 182 & $7,825.3$ & 190 \\
6 & 2,245 & $7,818.1$ & 173 & $7,818.1$ & 172 \\
7 & 2,985 & $7,793.8$ & 155 & $7,794.0$ & 154 \\
8 & 3,820 & $7,769.3$ & 151 & $7,769.6$ & 157 \\
9 & 4,285 & $7,756.0$ & 240 & $7,755.8$ & 230 \\
10 & 4,485 & $7,746.9$ & 145 & $7,747.1$ & 145 \\
11 & 6,255 & $7,698.3$ & 122 & $7,698.4$ & 127 \\
12 & 6,870 & $7,684.1$ & 144 & $7,683.6$ & 143 \\
\hline
\end{tabular}


Table 3. Cross-section characteristics of North Fork Eagle Creek, south-central New Mexico, 2018.

[ft, foot; $\mathrm{ft}^{2}$, square foot]

\begin{tabular}{ccccccccc}
\hline $\begin{array}{c}\text { Cross } \\
\text { section } \\
\text { number }\end{array}$ & $\begin{array}{c}\text { Bankfull } \\
\text { stage } \\
\text { (ft) }\end{array}$ & $\begin{array}{c}\text { Maximum } \\
\text { depth at } \\
\text { bankfull } \\
\text { stage } \\
\text { (ft) }\end{array}$ & $\begin{array}{c}\text { Cross-section } \\
\text { bankfull } \\
\text { channel width } \\
\text { (ft) }\end{array}$ & $\begin{array}{c}\text { Cross-section } \\
\text { bankfull } \\
\text { channel area } \\
\text { (ftt) }\end{array}$ & $\begin{array}{c}\text { Left bank } \\
\text { height } \\
\text { (ft) }\end{array}$ & $\begin{array}{c}\text { Left bank slope } \\
\text { (dimensionless) }\end{array}$ & $\begin{array}{c}\text { Right } \\
\text { bank } \\
\text { height } \\
\text { (ft) }\end{array}$ & $\begin{array}{c}\text { Right bank slope } \\
\text { (dimensionless) }\end{array}$ \\
\hline 1 & $7,891.3$ & 3.1 & 33.2 & 55.4 & 3.1 & 0.1 & 2.8 & 0.5 \\
2 & $7,879.7$ & 1.9 & 13.6 & 16.5 & 0.7 & 0.9 & 1.6 & 0.3 \\
3 & $7,868.8$ & 3.5 & 21.5 & 40.1 & 2.3 & 2.2 & 3.5 & 0.2 \\
4 & $7,846.3$ & 1.5 & 18.4 & 15.8 & 1.5 & 0.1 & 1.2 & 0.4 \\
5 & $7,827.0$ & 1.7 & 17.6 & 20.2 & 1.1 & 0.4 & 1.1 & 0.3 \\
6 & $7,822.2$ & 4.2 & 32.0 & 91.2 & 2.8 & 0.6 & 3.9 & 0.4 \\
7 & $7,797.1$ & 3.0 & 33.1 & 57.9 & 3.0 & 0.1 & 3.0 & 0.3 \\
8 & $7,774.0$ & 4.4 & 36.5 & 98.7 & 3.0 & 0.4 & 4.4 & 0.3 \\
9 & $7,758.1$ & 2.3 & 22.8 & 29.4 & 1.5 & 0.4 & 2.3 & 0.2 \\
10 & $7,751.2$ & 4.1 & 37.9 & 112.1 & 3.5 & 0.4 & 4.1 & 0.6 \\
11 & $7,706.0$ & 7.5 & 52.5 & 225.0 & 6.8 & 1.0 & 7.2 & 0.2 \\
12 & $7,685.5$ & 1.9 & 15.1 & 15.8 & 1.9 & 0.2 & 1.0 & 0.8 \\
13 & $7,640.5$ & 2.7 & 26.3 & 33.1 & 2.3 & 0.3 & 2.2 & 0.2 \\
14 & $7,622.0$ & 3.3 & 94.4 & 179.9 & 2.3 & 0.7 & 2.3 & 0.5 \\
\hline
\end{tabular}

At cross section 2, between the 2017 and 2018 surveys, the entire channel appeared to have degraded by about $0.6-0.8 \mathrm{ft}$, and the top of the right bank appeared to have eroded by about $0.8 \mathrm{ft}$ (fig. 7B). Additionally, an elevated area about $2.4 \mathrm{ft}$ tall and $14 \mathrm{ft}$ wide that was surveyed in 2017 on the right overbank did not appear to be present in 2018. The elevated area may have been composed of loose sediment or debris that washed away at some time between the two surveys.

At cross section 4, between the 2017 and 2018 surveys, the left side of the channel appeared to have eroded by about $10 \mathrm{ft}$, and the bed of the channel appeared to have aggraded by about $1.3 \mathrm{ft}$ (fig. 7D). However, in 2018, three of the left bank cross-section points were surveyed at poor accuracy, ranging from \pm 0.8 to $\pm 3.3 \mathrm{ft}$, and this cross section contained boulders that had diameters greater than $1 \mathrm{ft}$ (some of which appeared to substantially affect the cross-section plot on the right side of the channel). Therefore, the magnitude of the changes may not actually be as large as the survey results indicated. Though, some physical changes likely did occur at this cross section because it is in a location that is particularly susceptible to fluvial geomorphic change. Specifically, it is located at the site of one of the largest active debris jams in the study reach, which was observed in both 2017 and 2018, and it is located at a bend in the stream of more than 90 degrees. Further evidence that the left side of the channel had eroded between the two surveys was shown in photographs taken during the 2018 survey. The photographs showed a left bank defined by a fresh-looking soil surface with little to no vegetation.

At cross section 7, between the 2017 and 2018 surveys, the left side of the channel appeared to have aggraded by about $0.9 \mathrm{ft}$ (fig. $7 G$ ). Most notably, however, between 10 and $20 \mathrm{ft}$ from the left reference mark, part of the right overbank appeared to have degraded by about $2.0 \mathrm{ft}$. Further, based on photographs from the 2018 survey and aerial imagery of the study reach from March 2016, this degraded section was likely indicative of a side channel and not an isolated hole in the ground. Because the referenced aerial imagery was from March 2016, this side channel appeared to already be forming prior to the 2017 survey; however, the survey results indicated that the size of the side channel likely increased between the 2017 and 2018 surveys. 

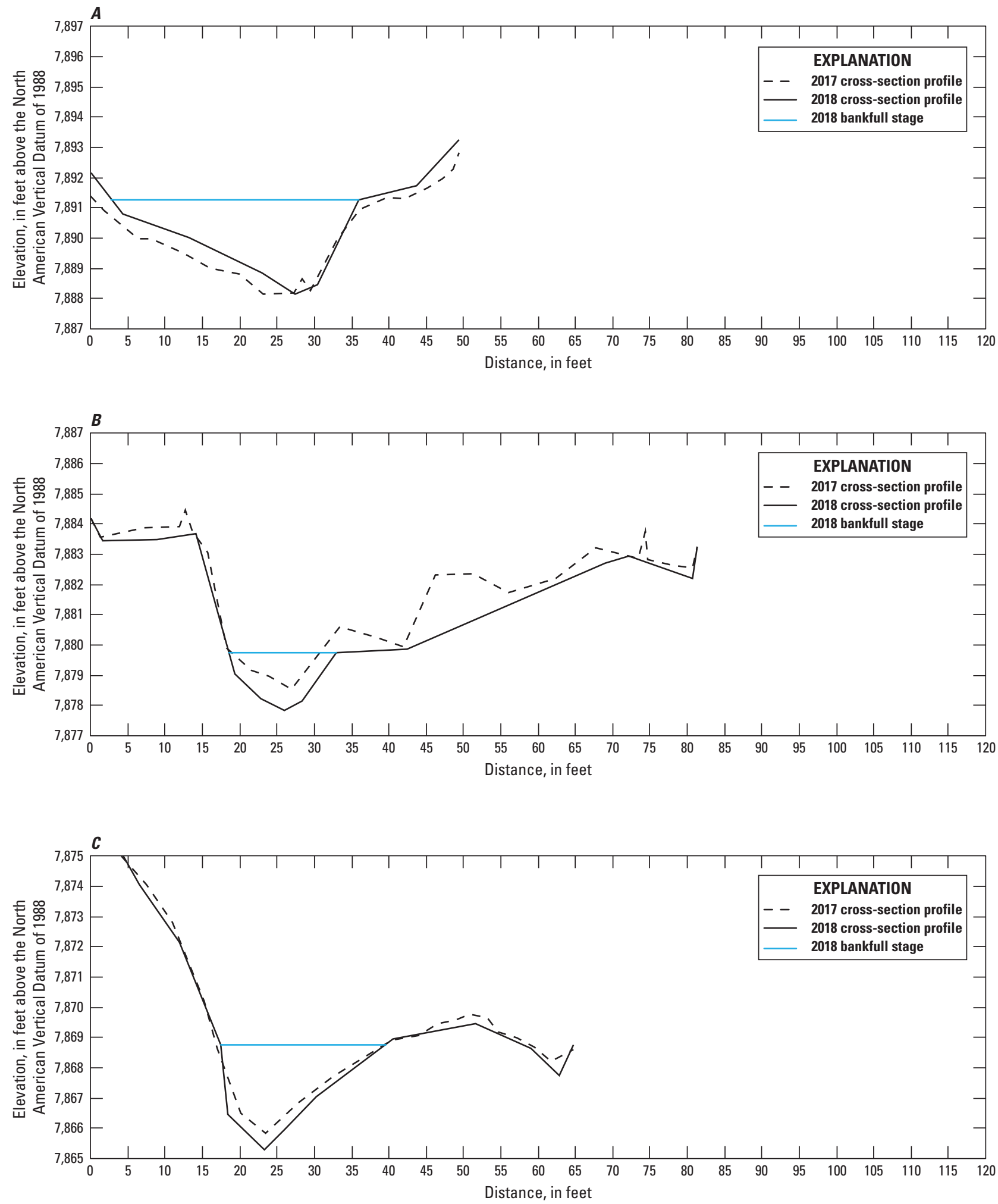

Figure 7. Cross sections from the 2017 and 2018 surveys plotted with 2018 estimates of bankfull stage for North Fork Eagle Creek, south-central New Mexico. Distances and elevations from 2017 have been corrected to the 2018 horizontal and vertical datums on the basis of the differences between the 2017 and 2018 cross-section reference mark locations and elevations. $A$, Cross section 1. $B$, Cross section 2. C, Cross section 3. D, Cross section 4. E, Cross section 5. F, Cross section 6. G, Cross section 7. H, Cross section 8. I, Cross section 9. J, Cross section 10. $K$, Cross section 11. L, Cross section 12. M, Cross section 13. N, Cross section 14. 

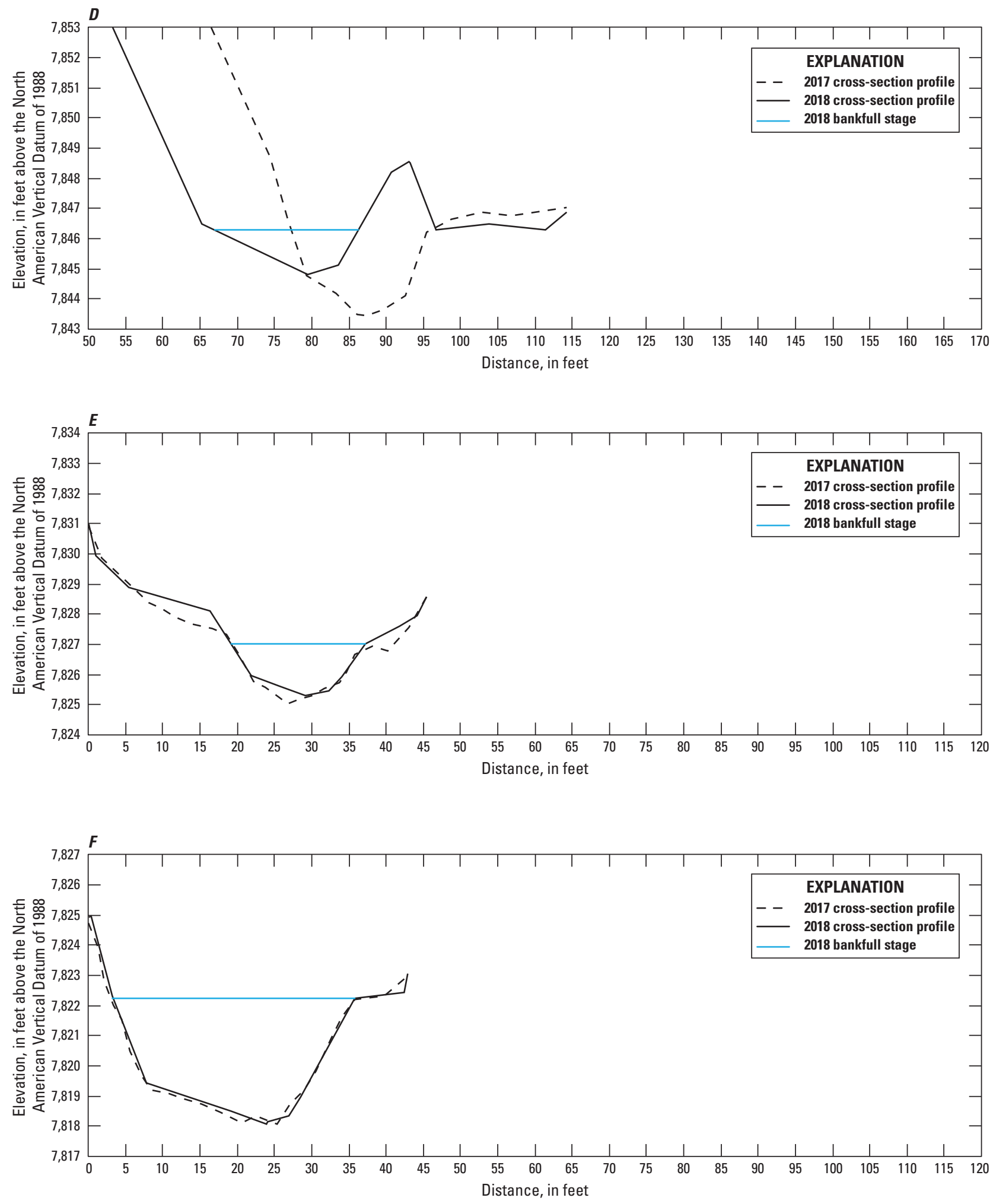

Figure 7. Cross sections from the 2017 and 2018 surveys plotted with 2018 estimates of bankfull stage for North Fork Eagle Creek, south-central New Mexico. Distances and elevations from 2017 have been corrected to the 2018 horizontal and vertical datums on the basis of the differences between the 2017 and 2018 cross-section reference mark locations and elevations. $A$, Cross section 1. $B$, Cross section 2. C, Cross section 3. D, Cross section 4. E, Cross section 5. F, Cross section 6. G, Cross section 7. H, Cross section 8. I, Cross section 9. J, Cross section 10. K, Cross section 11. L, Cross section 12. M, Cross section 13. N, Cross section 14.-Continued 

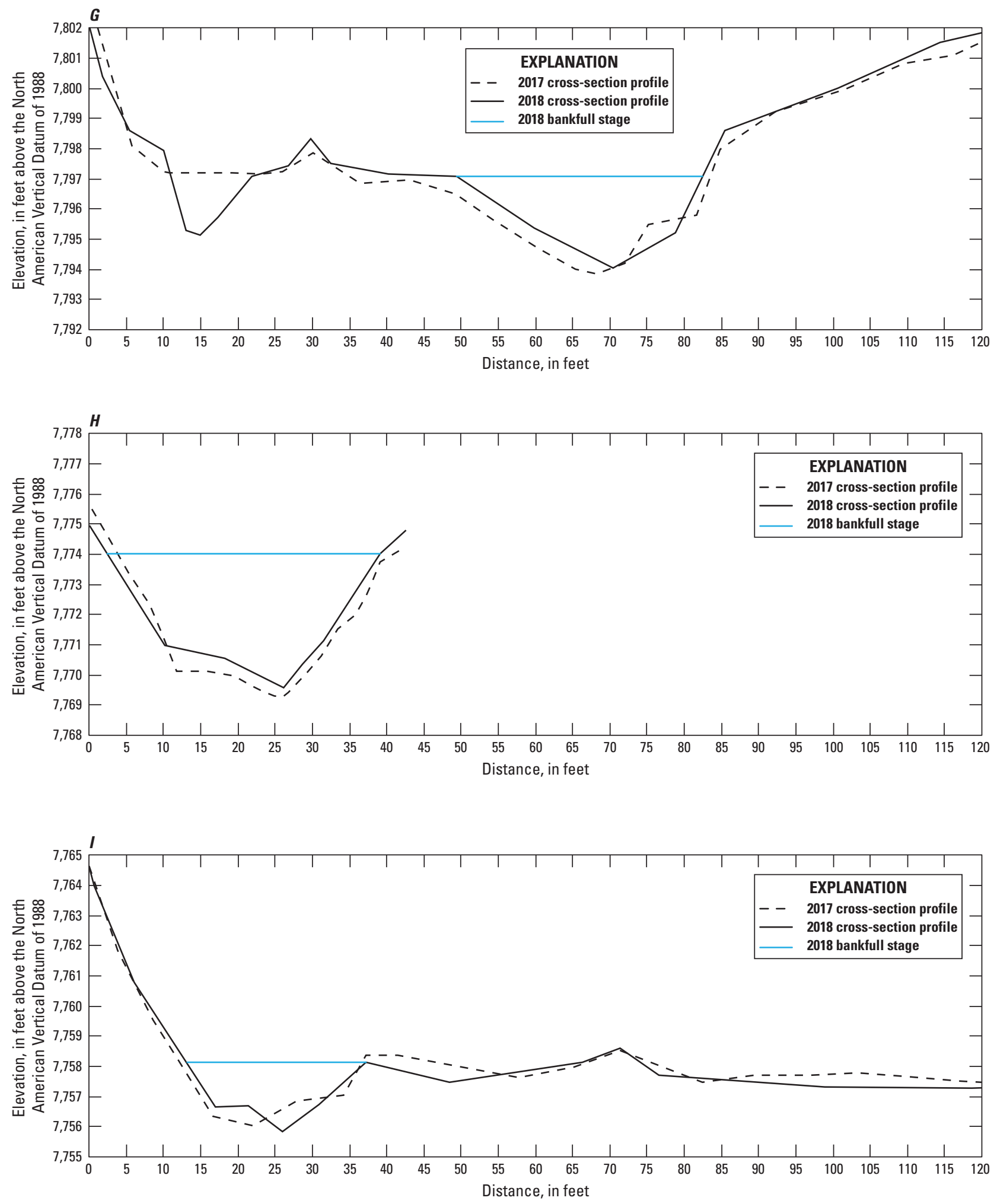

Figure 7. Cross sections from the 2017 and 2018 surveys plotted with 2018 estimates of bankfull stage for North Fork Eagle Creek, south-central New Mexico. Distances and elevations from 2017 have been corrected to the 2018 horizontal and vertical datums on the basis of the differences between the 2017 and 2018 cross-section reference mark locations and elevations. $A$, Cross section 1. B, Cross section 2. C, Cross section 3. D, Cross section 4. E, Cross section 5. F, Cross section 6. G, Cross section 7. H, Cross section 8. I, Cross section 9. J, Cross section 10. $K$, Cross section 11. L, Cross section 12. M, Cross section 13. N, Cross section 14.-Continued 

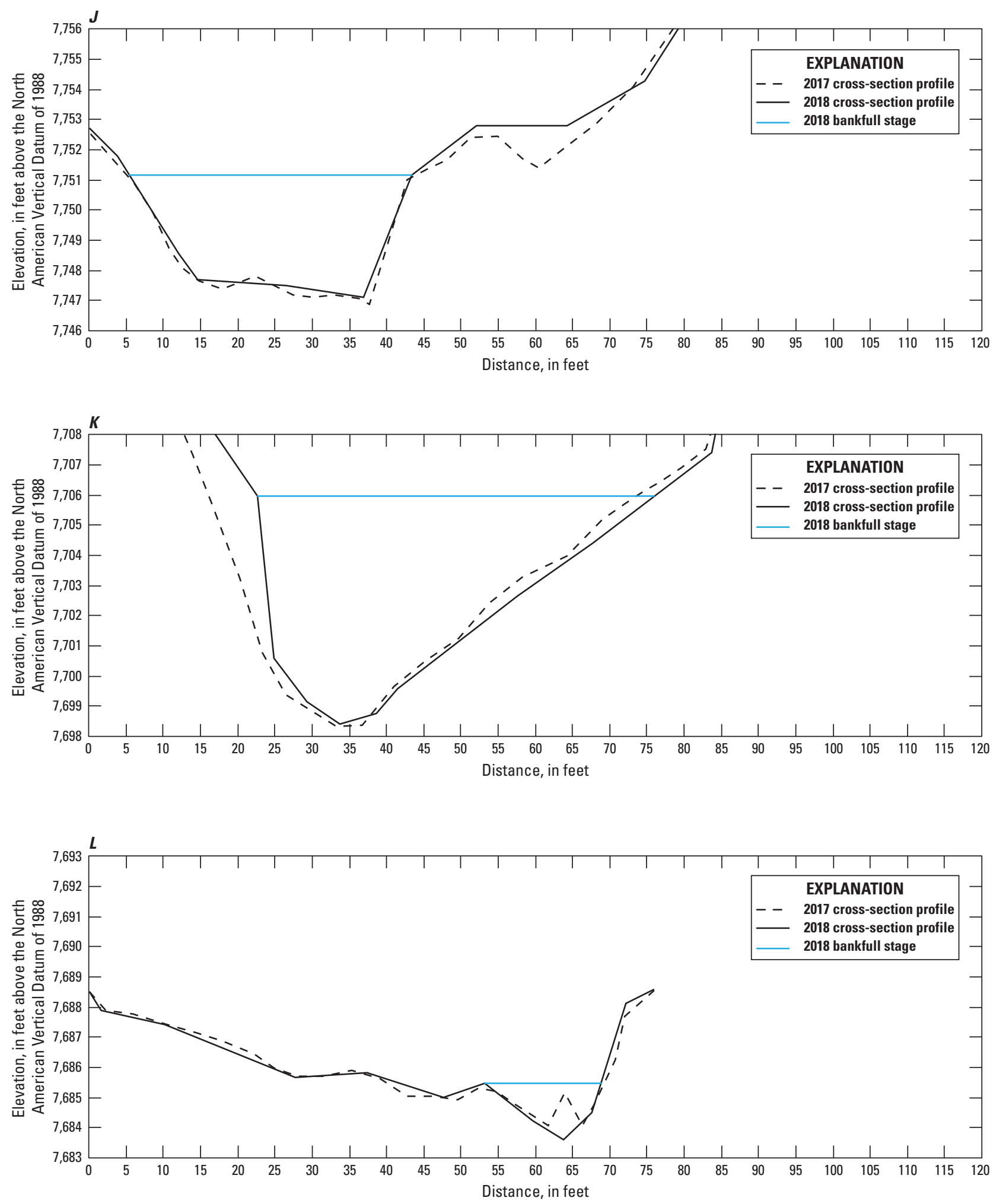

Figure 7. Cross sections from the 2017 and 2018 surveys plotted with 2018 estimates of bankfull stage for North Fork Eagle Creek, south-central New Mexico. Distances and elevations from 2017 have been corrected to the 2018 horizontal and vertical datums on the basis of the differences between the 2017 and 2018 cross-section reference mark locations and elevations. $A$, Cross section 1. B, Cross section 2. C, Cross section 3. D, Cross section 4. E, Cross section 5. F, Cross section 6. G, Cross section 7. H, Cross section 8. I, Cross section 9. J, Cross section 10. K, Cross section 11. L, Cross section 12. M, Cross section 13. N, Cross section 14.-Continued 

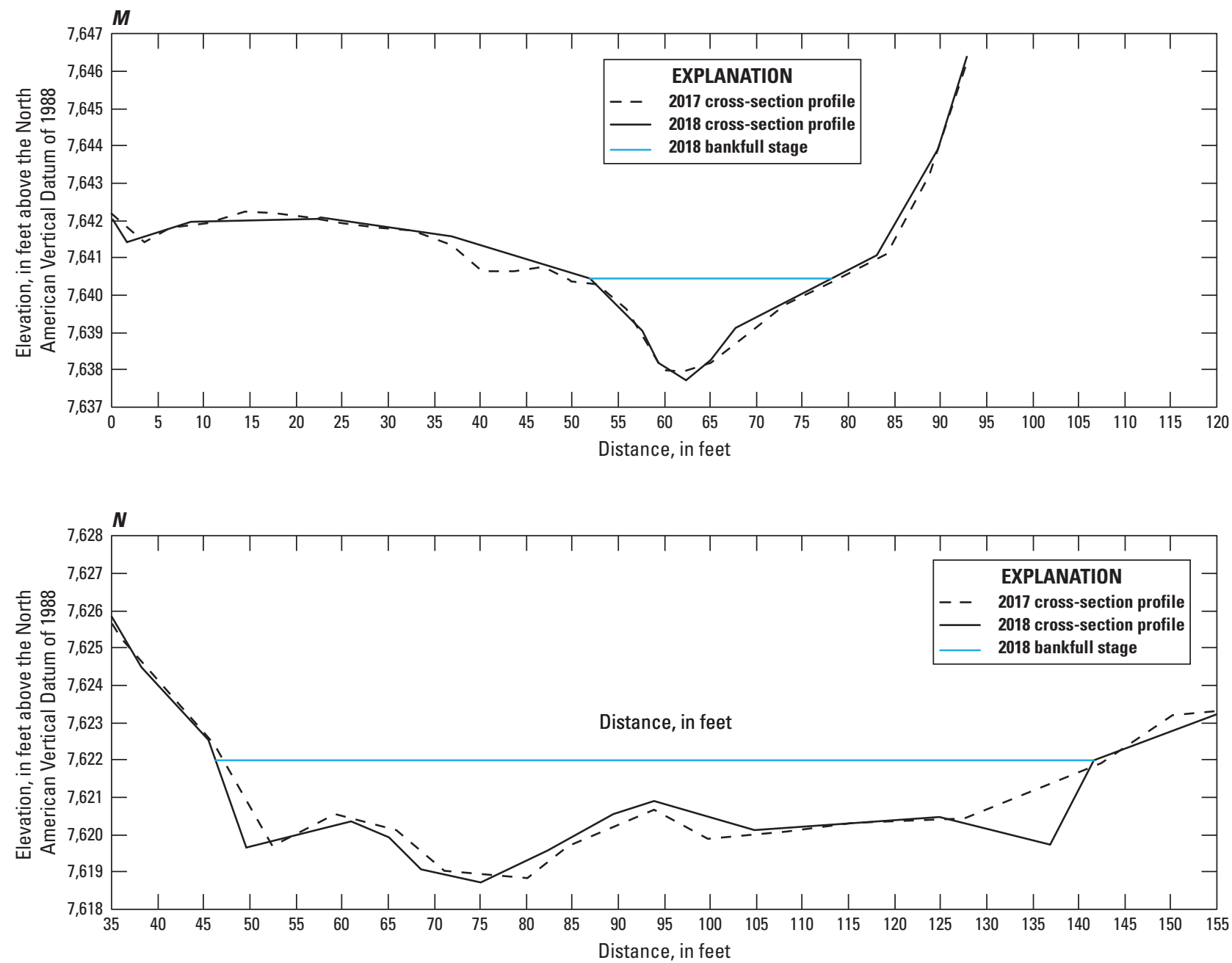

Figure 7. Cross sections from the 2017 and 2018 surveys plotted with 2018 estimates of bankfull stage for North Fork Eagle Creek, south-central New Mexico. Distances and elevations from 2017 have been corrected to the 2018 horizontal and vertical datums on the basis of the differences between the 2017 and 2018 cross-section reference mark locations and elevations. $A$, Cross section 1. B, Cross section 2. C, Cross section 3. D, Cross section 4. E, Cross section 5. F, Cross section 6. G, Cross section 7. H, Cross section 8. I, Cross section 9. J, Cross section 10. $K$, Cross section 11. L, Cross section 12. M, Cross section 13. N, Cross section 14.-Continued 


\section{Woody Debris}

During the 2018 survey, there were 112 distinct accumulations of woody debris identified in the study reach (fig. 8A; table 4). Of these, 39 were identified as debris deposits, 16 were identified as potential debris jams, and 57 were identified as active debris jams (fig. $8 A$; table 4 ). During the 2017 survey, there were 58 distinct accumulations of woody debris identified in the study reach, with 17 identified as debris deposits, 25 identified as potential debris jams, and 16 identified as active debris jams (Graziano, 2019).

Though the woody debris accumulation totals from 2017 and 2018 were quite different from each other, there were some similarities found in the distribution of woody debris accumulations between the two years. In 2018, the highest concentration of woody debris accumulations was identified in the upstream subreach, defined here as the reach segment between the first road crossing (located about $165 \mathrm{ft}$ upstream from cross section 1) and cross section 10 (subreach length of about 4,485 ft), where 67 accumulations of woody debris were identified (an average rate of about 15 woody debris accumulations per $1,000 \mathrm{ft}$ ) (fig. $8 B$; table 4). In the downstream subreach, defined here as the reach segment between cross section 10 and the Eagle Creek gaging station (subreach length of about 5,505 ft), 45 accumulations of woody debris were identified in 2018 (an average rate of about 8 woody debris accumulations per $1,000 \mathrm{ft}$ ) (fig. $8 C$; table 4). In other words, 60 percent of the woody debris accumulations were identified in the upstream subreach, and 40 percent of the woody debris accumulations were identified in the downstream subreach. In 2017, 64 percent of the woody debris accumulations were identified in the same upstream subreach (excluding the $165 \mathrm{ft}$ upstream from cross section 1), and 36 percent were identified in the same downstream subreach.

Though the distribution of woody debris accumulations between the upstream and downstream subreaches was similar in 2018 and 2017, there were some appreciable differences in the distribution of woody debris accumulations within smaller scale cross-section-defined reach segments. The most notable difference was found in the reach segment between cross sections 8 and 11 . That reach segment, which extends into both the upstream and downstream subreaches, has a length of $2,435 \mathrm{ft}$ (approximately one-quarter of the study reach length), and in 2017 only three distinct accumulations of woody debris were identified in it (an average rate of about one woody debris accumulation per 1,000 ft) (Graziano, 2019). In 2018, there were 27 distinct accumulations of woody debris identified in that reach segment (an average rate of about 11 woody debris accumulations per 1,000 ft) (table 4).

Through comparison of the locations and photographs of woody debris accumulations from the 2017 and 2018 surveys, it was determined that differences in the total woody debris accumulations and distributions were primarily due to actual changes that occurred in the study reach and were not due to differences in the application of the methods used to identify woody debris accumulations or due to changes in the extent of the study reach. Specifically, it was determined that there were 49 accumulations of woody debris (11 debris deposits, 7 potential debris jams, and 31 active debris jams) identified in the study reach in 2018 that were not identified in 2017 and likely settled in their 2018 locations sometime between the 2017 and 2018 surveys. Further, there were 34 accumulations of woody debris (16 debris deposits, 15 potential debris jams, and 3 active debris jams) surveyed in 2017 that were not identified in 2018 and were likely transported away from their 2017 locations sometime between the 2017 and 2018 surveys.

It was considered that certain accumulations of woody debris identified in 2018 may have been overlooked during the 2017 survey. Those included, for example, accumulations that were relatively small and accumulations that were found entirely on one side of the channel rather than in the middle. It was determined that 37 of the accumulations of woody debris ( 25 debris deposits, 4 potential debris jams, and 8 active debris jams) identified in 2018 fell into this category; therefore, they were not included in the 49 woody debris accumulations that likely settled in their 2018 locations sometime between the 2017 and 2018 surveys, though it is still possible that they were not overlooked and instead settled in their 2018 locations sometime between the 2017 and 2018 surveys.

Regarding changes due to differences in the application of the methods used to identify woody debris accumulations, there were two accumulations of woody debris (both were classified as active debris jams) surveyed in 2018 that had been identified as four separate accumulations of woody debris (all four were classified as active debris jams) during the 2017 survey. Regarding changes in the extent of the study reach, in 2018, there were only four accumulations of woody debris (all four were classified as active debris jams) that were identified in the newly surveyed area upstream from cross section 1.

Ultimately, the findings indicated that of the 112 distinct accumulations of woody debris surveyed in 2018 only 22 ( 20 percent) were certain to have also been present during the 2017 survey. However, some of these woody debris accumulations that remained in place had undergone observable changes to their sizes, compositions, and structures, though they all maintained some woody debris that they could be recognized by, such as their key members.

Of the 22 woody debris accumulations identified during the 2018 survey that were certain to have also been present during the 2017 survey, 12 had the same classification in 2018 ( 8 active debris jams and 4 potential debris jams). There were six potential debris jams that became active debris jams, there was one debris deposit that became an active debris jam, there was one active debris jam that became a potential debris jam, and there were two active debris jams that became debris deposits. These changes in classification were all due to observable changes in the structure and composition of the woody debris accumulations. Regarding the two active debris jams that became debris deposits, large identifiable wood was still present in the accumulations, but the jams appeared to have been broken up, and the larger wood from them was left loosely scattered in about the same location. 


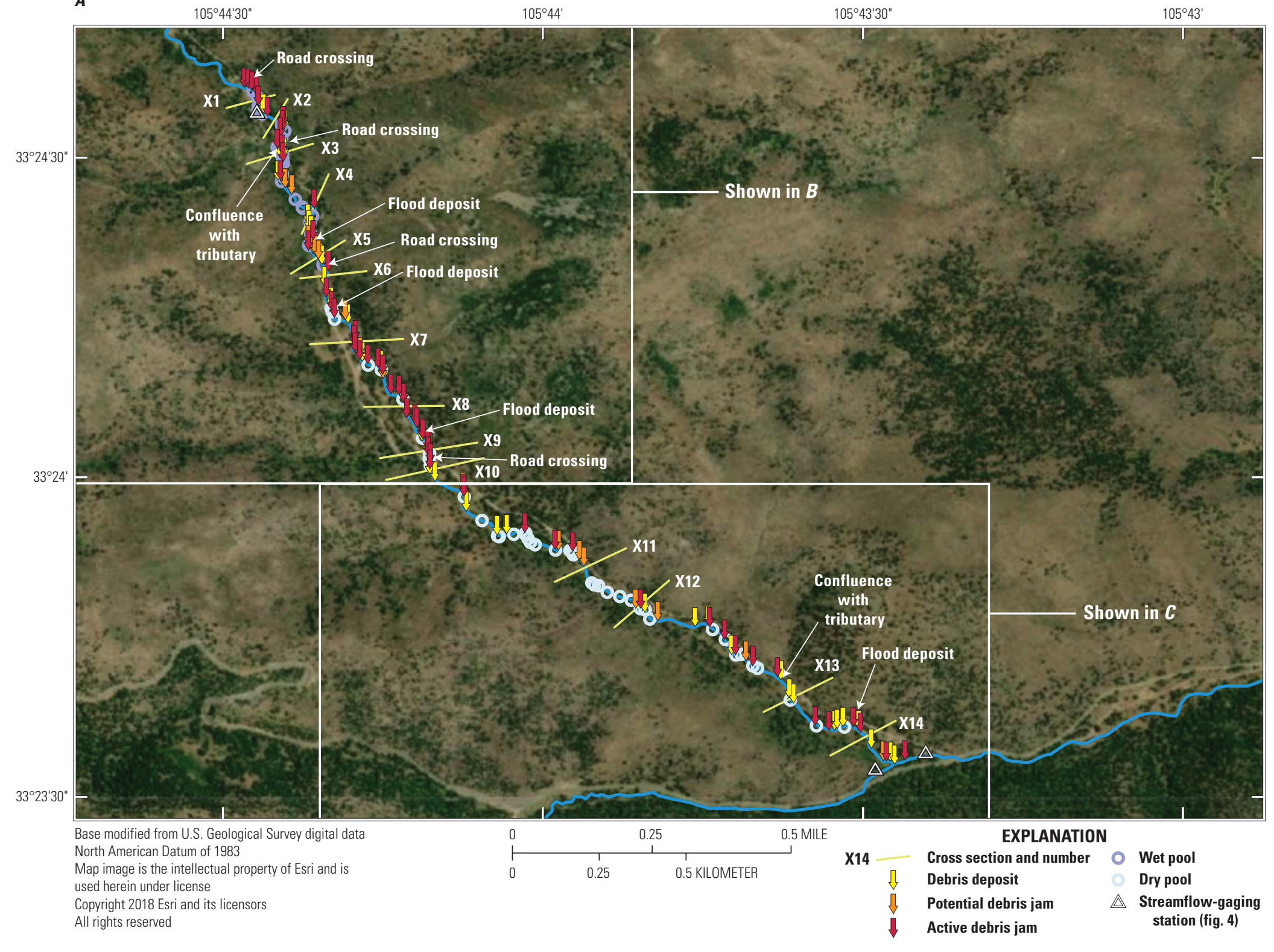

Figure 8. Study reach with locations of woody debris accumulations and pools relative to the locations of cross sections, streamflow-gaging stations, and other features in the Eagle Creek Basin, south-central New Mexico, 2018. Cross-section lengths are exaggerated for presentation purposes. $A$, Study reach. $B$, Upstream subreach. C, Downstream subreach. 


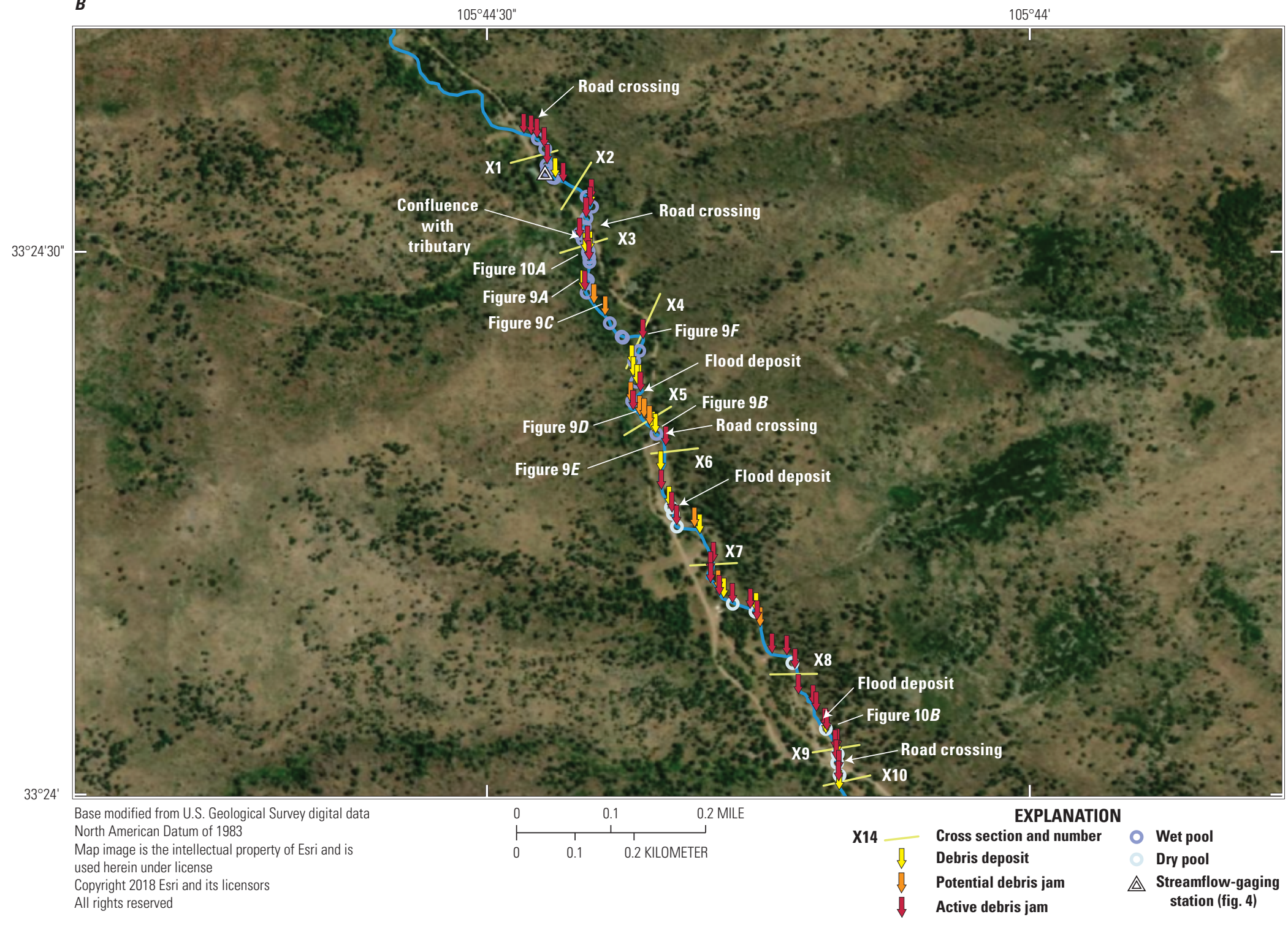

Figure 8. Study reach with locations of woody debris accumulations and pools relative to the locations of cross sections, streamflow-gaging stations, and other features in the Eagle Creek Basin, south-central New Mexico, 2018. Cross-section lengths are exaggerated for presentation purposes. $A$, Study reach. $B$, Upstream subreach. $C$, Downstream subreach.-Continued 


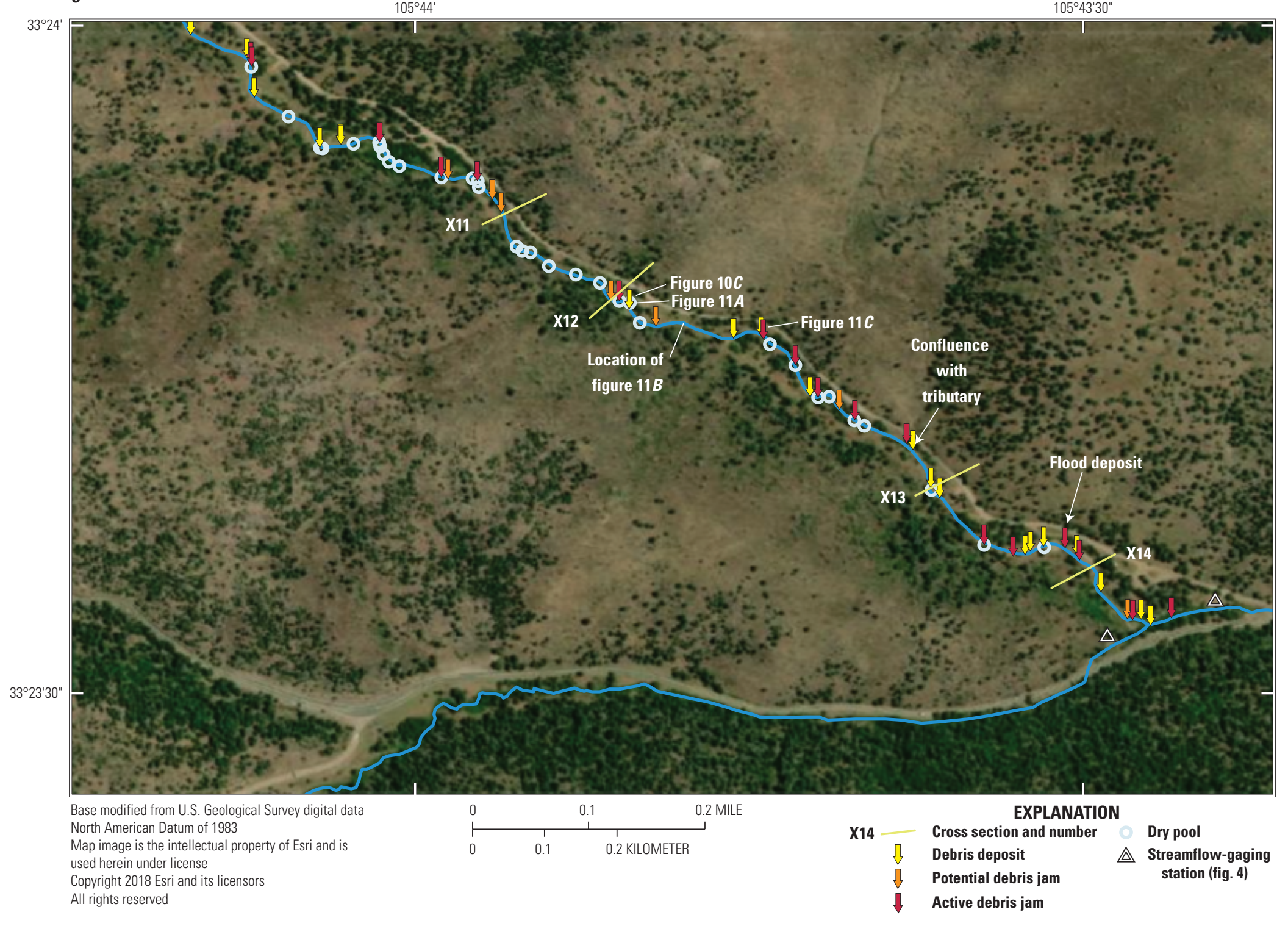

Figure 8. Study reach with locations of woody debris accumulations and pools relative to the locations of cross sections, streamflow-gaging stations, and other features in the Eagle Creek Basin, south-central New Mexico, 2018. Cross-section lengths are exaggerated for presentation purposes. $A$, Study reach. $B$, Upstream subreach. C, Downstream subreach.-Continued 
Table 4. Locations, classifications, and average rates of woody debris accumulations in the study reach, Eagle Creek Basin, south-central New Mexico, 2018.

[Reach lengths are based on study reach trace in figure 4 and are rounded to the nearest 5 feet; average rates were calculated for each reach as total number of woody debris accumulations per 1,000 feet; $\mathrm{ft}$, foot; $\mathrm{X}$, cross section]

\begin{tabular}{|c|c|c|c|c|c|c|}
\hline \multirow[t]{2}{*}{ Reach } & \multirow[t]{2}{*}{$\begin{array}{l}\text { Reach } \\
\text { length } \\
\text { (ft) }\end{array}$} & \multicolumn{3}{|c|}{$\begin{array}{c}\text { Number of woody debris accumulations } \\
\text { by classification }\end{array}$} & \multirow[t]{2}{*}{$\begin{array}{l}\text { Total number of } \\
\text { woody debris } \\
\text { accumulations }\end{array}$} & \multirow{2}{*}{$\begin{array}{c}\text { Average rate of } \\
\text { woody debris } \\
\text { accumulations } \\
\text { (per } 1,000 \mathrm{ft} \text { ) }\end{array}$} \\
\hline & & $\begin{array}{c}\text { Debris } \\
\text { deposit }\end{array}$ & $\begin{array}{c}\text { Potential } \\
\text { debris jam }\end{array}$ & $\begin{array}{c}\text { Active } \\
\text { debris jam }\end{array}$ & & \\
\hline First road crossing to $\mathrm{X} 1$ & 165 & 0 & 0 & 4 & 4 & 24 \\
\hline $\mathrm{X} 1$ to $\mathrm{X} 2$ & 275 & 1 & 0 & 2 & 3 & 11 \\
\hline $\mathrm{X} 2$ to $\mathrm{X} 3$ & 385 & 1 & 0 & 4 & 5 & 13 \\
\hline $\mathrm{X} 3$ to $\mathrm{X} 4$ & 670 & 3 & 2 & 3 & 8 & 12 \\
\hline $\mathrm{X} 4$ to $\mathrm{X} 5$ & 550 & 4 & 3 & 3 & 10 & 18 \\
\hline $\mathrm{X} 5$ to $\mathrm{X} 6$ & 200 & 2 & 1 & 1 & 4 & 20 \\
\hline $\mathrm{X} 6$ to $\mathrm{X} 7$ & 740 & 3 & 1 & 4 & 8 & 11 \\
\hline $\mathrm{X} 7$ to $\mathrm{X} 8$ & 835 & 2 & 2 & 9 & 13 & 16 \\
\hline $\mathrm{X} 8$ to $\mathrm{X} 9$ & 465 & 1 & 0 & 6 & 7 & 15 \\
\hline $\mathrm{X} 9$ to $\mathrm{X} 10$ & 200 & 1 & 0 & 4 & 5 & 25 \\
\hline $\mathrm{X} 10$ to $\mathrm{X} 11$ & 1,770 & 7 & 3 & 5 & 15 & 8 \\
\hline $\mathrm{X} 11$ to $\mathrm{X} 12$ & 615 & 0 & 1 & 0 & 1 & 2 \\
\hline $\mathrm{X} 12$ to $\mathrm{X} 13$ & 1,690 & 6 & 2 & 6 & 14 & 8 \\
\hline $\mathrm{X} 13$ to $\mathrm{X} 14$ & 790 & 5 & 0 & 4 & 9 & 11 \\
\hline X14 to the Eagle Creek gaging station & 640 & 3 & 1 & 2 & 6 & 9 \\
\hline Study reach & 9,990 & 39 & 16 & 57 & 112 & 11 \\
\hline
\end{tabular}

Example photographs of different woody debris accumulations identified during the 2018 survey are presented in figure 9 , and the locations of the examples are shown in figure 8 . Figure $9 \mathrm{~A}$ depicts a type of debris deposit that was commonly seen during the 2018 survey, that being a debris deposit made up of woody debris loosely scattered on the side of the channel rather than in the middle. The debris deposit shown in figure $9 A$ was not identified during the 2017 survey; however, because this debris deposit was almost entirely on the right side of the channel, it is possible that it was present in the channel during the 2017 survey and therefore was categorized as one of the 25 debris deposits that may have been overlooked in 2017. Notably, during the 2017 and 2018 surveys, in many locations along the study reach, deposits of LWD were observed on the channel banks or in the floodplain, but these woody debris accumulations were not photographed, cataloged, or surveyed.

Figure $9 B$ depicts a type of debris deposit less commonly seen during the 2018 survey, that being a debris deposit that both included many pieces of woody debris and spanned most of the channel. The debris deposit depicted in figure $9 B$ was found about $5 \mathrm{ft}$ downstream from the third road crossing (located between cross sections 5 and 6 ) where no bridge is present and North Fork Eagle Creek crosses over the road. It appeared that what had caused woody debris to accumulate in this location was a combination of effects from the sheer drop in the channel of about $5 \mathrm{ft}$ at the downstream side of the road crossing and the gravel bar located about $5 \mathrm{ft}$ downstream from the drop. The debris deposit depicted in figure $9 B$ was 1 of the 11 debris deposits that were presumed to have newly formed between the 2017 and 2018 surveys because it was not observed in 2017, and due to its size and extent, it was not likely to have been overlooked during the 2017 survey.

Figure $9 C$ depicts a common type of potential debris jam, that being a potential debris jam formed by LWD suspended over the channel that may not have been deposited by streamflow (for example, it could have fallen across the channel) but would likely require wood-mobilizing streamflows to become an active debris jam. Notably, wood-mobilizing streamflows may also be capable of removing the LWD in figure $9 C$ from its location. However, the LWD in figure $9 C$ was also identified during the 2017 survey and was one of the four woody debris accumulations that were classified as potential debris jams in both 2017 and 2018. Additionally, there were high, wood-mobilizing streamflows that occurred between the 2017 and 2018 surveys, and they did not cause notable change to the LWD in figure $9 C$. 

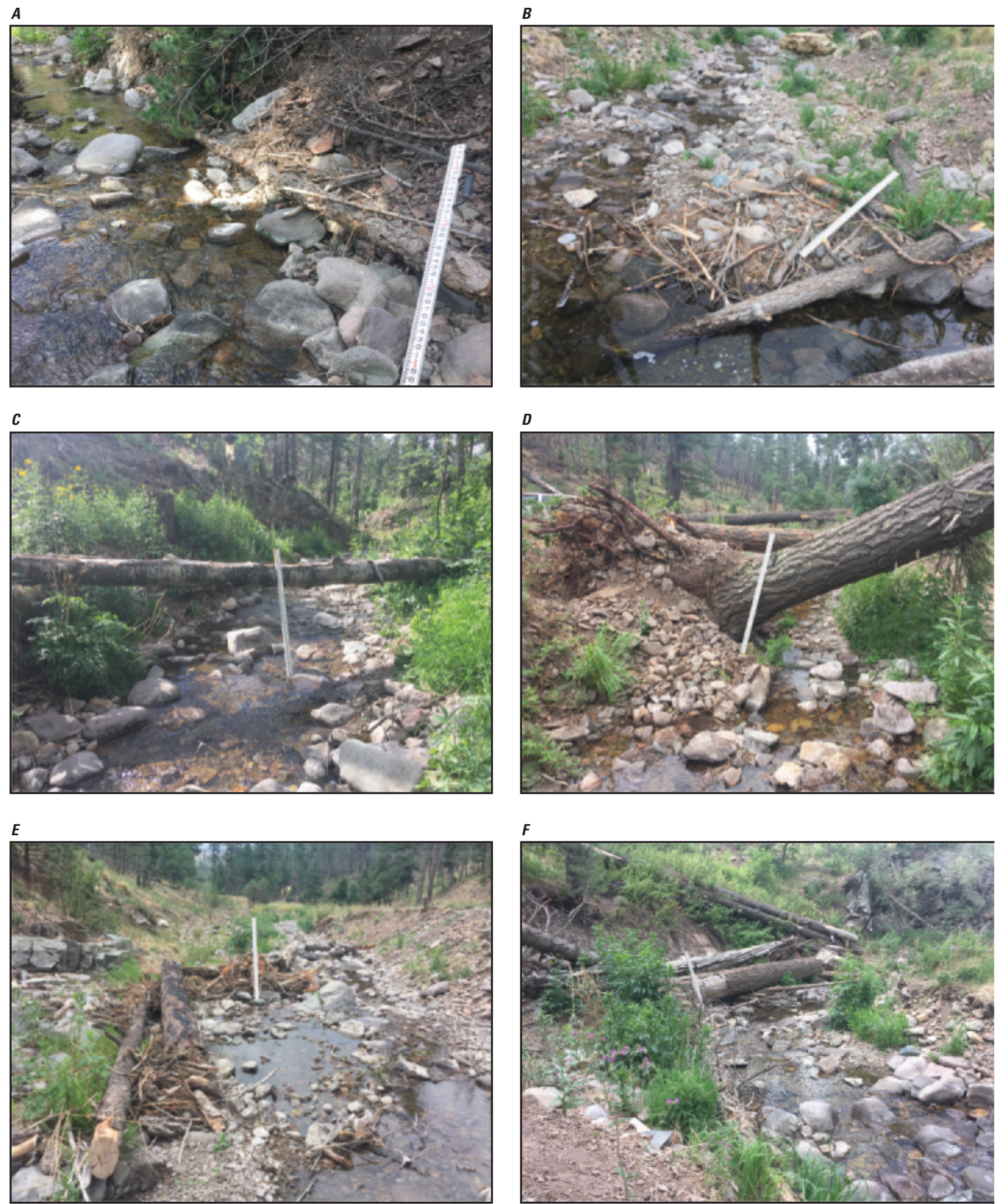

Figure 9. Examples of woody debris accumulations identified in North Fork Eagle Creek, south-central New Mexico, 2018. All photographs were taken facing downstream. For scale, a survey rod that is 4.46 feet in length (with graduation at feet, tenths of feet, and hundredths of feet) was included in each photograph. Locations of examples are shown in figure 8. $A$, Debris deposit. $B$, Debris deposit.

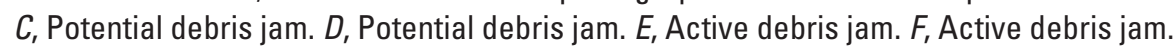


Figure $9 D$ depicts a unique potential debris jam that was one of the seven potential debris jams that was presumed to have newly formed between 2017 and 2018. This potential debris jam was unique in that it was the only potential debris jam that appeared to have contributed to relatively substantial geomorphic change in the channel, specifically, where the tree uprooted on the left bank, the left bank collapsed, and the channel became constricted. It was also unique because it can be said with certainty that it was not woody debris that was mobilized and deposited by streamflow. Further, because the tree was large (between 2 and $3 \mathrm{ft}$ in diameter) and it appeared to be firmly anchored by its root structure, it is likely that it will remain in place unless there is a substantial increase in streamflow or it is removed by artificial means. Therefore, it is likely well suited to become the key member in an active debris jam and to continue to be a driver of geomorphic change in the location where it was found during the 2018 survey.

Figure $9 E$ depicts an active debris jam with characteristics that were common to most of the active debris jams identified in the study reach in 2018. Specifically, the active debris jam contained small woody debris packed tightly against LWD key members, mostly on the upstream side. Also, like in most other active debris jams identified in 2018, the key members do not appear to be firmly anchored; therefore, the active debris jam could likely be mobilized and transported by high flows without putting up much resistance. Other characteristics of the active debris jam in figure $9 E$ were less common. Specifically, because the active debris jam extended about 20-30 ft down the left side of the channel, it was longer than most of the active debris jams observed in 2018, which were generally 5-10 ft long channelwise. Additionally, most active debris jams in the reach contained one or two pieces of LWD with smaller woody debris packed tightly against those pieces of LWD in a single location. In the active debris jam depicted in figure $9 E$, there were several pieces of LWD that all appeared to be serving as key members in the jam, and there were multiple locations along the debris jam where smaller woody debris had packed tightly against those pieces of LWD. Another notable characteristic of the active debris jam depicted in figure $9 E$ was that some of the wood was charred, possibly because of the 2012 Little Bear Fire. Charred wood or burn-marked wood was present in at least 17 woody debris accumulations (15 percent of the total woody debris accumulations). The active debris jam depicted in figure $9 E$ was 1 of the 31 active debris jams that were presumed to have newly formed between the 2017 and 2018 surveys because it was not observed in 2017, and because of its size and extent, it was not likely to have been overlooked during the 2017 survey.

Figure $9 F$ depicts what appeared to be the largest (by volume) active debris jam found in the study reach in 2018. It is located about $5-10 \mathrm{ft}$ downstream from cross section 4 on the outer edge of a 90-plus degree bend in the channel. The active debris jam depicted in figure $9 F$ was one of the eight active debris jams that was present during both the 2017 and 2018 surveys, and a photograph of it from the 2017 survey was used as an example of an active debris jam in Graziano
(2019). Because the active debris jam depicted in figure $9 F$ is of a relatively large size and remained in place through the high flows that occurred between the two surveys, while the topography of cross section 4 just 5-10 ft upstream appeared to change, it is possibly an accumulation of woody debris that has influenced geomorphic change in the study reach. It is also possible that it will influence future geomorphic change in the study reach.

The woody debris changes between the 2017 and 2018 surveys seemed to indicate that the high flows that occurred in the study reach during the period between the two surveys were substantial enough to transport most of the woody debris accumulations identified in 2017 (34 of the 58 woody debris accumulations [59 percent] identified in 2017 were not found again in 2018). However, those same high flows were not substantial enough to transport a majority of the more firmly anchored woody debris accumulations found in 2017. This is evidenced by the findings that 13 of the 16 active debris jams and 10 of the 25 potential debris jams (56 percent of the total active and potential debris jams) identified during the 2017 survey were found in the same locations in some form during the 2018 survey.

\section{Pools}

During the 2018 survey, there were 71 pools identified in the study reach (fig. $8 A$; table 5). Of the 71 pools identified, 42 were identified in the dry section of the study reach (which is the lower $1.45 \mathrm{mi}$ of the study reach that begins about $100 \mathrm{ft}$ downstream from cross section 6), and 29 were identified in the wet section of the study reach (which is the upper $0.44 \mathrm{mi}$ of the study reach) (fig. $8 A$; table 5). Residual depths for all pools ranged from $0.19 \mathrm{ft}$ (one pool in the reach segment between the first road crossing and cross section 1) to $2 \mathrm{ft}$ (three pools in the dry section of the study reach) (Graziano, 2020). On the basis of their residual depths, 39 pools were classified as shallow, 18 were classified as intermediate, and 14 were classified as deep (table 5).

During the 2018 survey, 39 pools were identified in the 4,485-ft upstream subreach (an average rate of about 9 pools per 1,000 ft) (fig. 8B; table 5), and 32 pools were identified in the 5,505-ft downstream subreach (an average rate of about 6 pools per $1,000 \mathrm{ft}$ ) (fig. $8 C$; table 5 ). Within the upstream subreach, a dense cluster of pools was found in the reach segment that extended from the second road crossing (located between cross sections 2 and 3) to about $100 \mathrm{ft}$ downstream from cross section 3 . In that reach segment, which has a length of about $220 \mathrm{ft}, 9$ pools were identified, which, if extrapolated, would be an average rate of about 41 pools per $1,000 \mathrm{ft}$ (fig. 8B) (Graziano, 2020). Within the downstream subreach, the downstream half of the reach segment between cross sections 10 and 11 (length of about $885 \mathrm{ft}$ ) was notable because it contained 7 of the 14 deep pools identified in the study reach (that is, half of the deep pools found in the study reach were identified in a reach segment that made up less than 9 percent of the study reach) (fig. 8C) (Graziano, 2020). 
Table 5. Locations, residual depth classifications, dry or wet indications, and average rates of pools in the study reach, Eagle Creek Basin, south-central New Mexico, 2018.

[Reach lengths are based on study reach trace in figure 4 and are rounded to the nearest 5 feet; average rates were calculated for each reach as total number of pools per 1,000 feet; ft, foot; <, less than; >, greater than; X, cross section]

\begin{tabular}{|c|c|c|c|c|c|c|c|c|}
\hline \multirow[t]{2}{*}{ Reach } & \multirow[t]{2}{*}{$\begin{array}{l}\text { Reach } \\
\text { length } \\
\text { (ft) }\end{array}$} & \multicolumn{3}{|c|}{$\begin{array}{l}\text { Number of pools by residual } \\
\text { depth classification }\end{array}$} & \multirow[t]{2}{*}{$\begin{array}{c}\text { Total } \\
\text { number of } \\
\text { dry pools }\end{array}$} & \multirow[t]{2}{*}{$\begin{array}{c}\text { Total } \\
\text { number of } \\
\text { wet pools }\end{array}$} & \multirow[t]{2}{*}{$\begin{array}{c}\text { Total } \\
\text { number of } \\
\text { pools }\end{array}$} & \multirow[t]{2}{*}{$\begin{array}{c}\text { Average } \\
\text { rate of pools } \\
\text { (per } 1,000 \mathrm{ft} \text { ) }\end{array}$} \\
\hline & & $\begin{array}{l}\text { Shallow } \\
(<0.75 \mathrm{ft})\end{array}$ & $\begin{array}{l}\text { Intermediate } \\
(0.75-1.25 \mathrm{ft})\end{array}$ & $\begin{array}{c}\text { Deep } \\
(>1.25 \mathrm{ft})\end{array}$ & & & & \\
\hline First road crossing to $\mathrm{X} 1$ & 165 & 2 & 0 & 0 & 0 & 2 & 2 & 12 \\
\hline $\mathrm{X} 1$ to $\mathrm{X} 2$ & 275 & 2 & 1 & 1 & 0 & 4 & 4 & 15 \\
\hline $\mathrm{X} 2$ to $\mathrm{X} 3$ & 385 & 4 & 2 & 0 & 0 & 6 & 6 & 16 \\
\hline $\mathrm{X} 3$ to $\mathrm{X} 4$ & 670 & 11 & 1 & 0 & 0 & 12 & 12 & 18 \\
\hline $\mathrm{X} 4$ to $\mathrm{X} 5$ & 550 & 4 & 0 & 0 & 0 & 4 & 4 & 7 \\
\hline $\mathrm{X} 5$ to $\mathrm{X} 6$ & 200 & 0 & 1 & 0 & 0 & 1 & 1 & 5 \\
\hline $\mathrm{X} 6$ to $\mathrm{X} 7$ & 740 & 3 & 0 & 0 & 3 & 0 & 3 & 4 \\
\hline $\mathrm{X} 7$ to $\mathrm{X} 8$ & 835 & 2 & 1 & 0 & 3 & 0 & 3 & 4 \\
\hline $\mathrm{X} 8$ to $\mathrm{X} 9$ & 465 & 0 & 0 & 1 & 1 & 0 & 1 & 2 \\
\hline $\mathrm{X} 9$ to $\mathrm{X} 10$ & 200 & 0 & 2 & 1 & 3 & 0 & 3 & 15 \\
\hline $\mathrm{X} 10$ to $\mathrm{X} 11$ & 1,770 & 6 & 1 & 7 & 14 & 0 & 14 & 8 \\
\hline $\mathrm{X} 11$ to $\mathrm{X} 12$ & 615 & 1 & 3 & 2 & 6 & 0 & 6 & 10 \\
\hline $\mathrm{X} 12$ to $\mathrm{X} 13$ & 1,690 & 3 & 4 & 2 & 9 & 0 & 9 & 5 \\
\hline $\mathrm{X} 13$ to X14 & 790 & 1 & 2 & 0 & 3 & 0 & 3 & 4 \\
\hline $\begin{array}{l}\mathrm{X} 14 \text { to the Eagle Creek } \\
\text { gaging station }\end{array}$ & 640 & 0 & 0 & 0 & 0 & 0 & 0 & 0 \\
\hline Study reach & 9,990 & 39 & 18 & 14 & 42 & 29 & 71 & 7 \\
\hline
\end{tabular}

During the 2017 survey, only 14 pools were identified in the study reach; they were not measured for residual depth, and they were only identified in the upper two-thirds of the study reach (Graziano, 2019). Because methods for identifying and measuring pools had not been well established prior to the 2017 survey, it is likely that many of the shallower pools in the study reach, especially in the dry sections, were overlooked in 2017; therefore, the pool totals from 2017 and 2018 are not presumed to be directly comparable. However, there were some general similarities in the distributions of pools seen during the 2017 and 2018 surveys. Specifically, in 2017, like in 2018, relatively dense clusters of pools were identified near cross sections 3 and 11, with three pools being found near cross section 3 and four pools being found near cross section 11 (Graziano, 2019).

Though the pool totals from the two years were not presumed to be directly comparable because of differences in the methods used to identify pools and, to a much lesser extent, because of changes in the extent of the study reach, there were likely some actual changes to the pools in the study reach. This was determined through comparison of the locations and photographs of pools from the 2017 and 2018 surveys. The most compelling evidence that pools in the study reach had changed was that there were five pools identified during the 2017 survey that were not identified during the more thorough 2018 survey. Between the 2017 and 2018 surveys, those five pools likely filled in or physically changed in some other way that prevented them from being identified as pools in 2018. Further evidence of change to pools in the study reach included the finding that at least 10 of the pools identified during the 2018 survey were colocated with active debris jams that may have influenced the formation of the pools through their effects on local flow dynamics. In contrast, the pools identified during the 2017 survey were not colocated with any of the woody debris accumulations identified during that survey (Graziano, 2019). Regarding the other results of the location and photograph comparisons, there were 7 pools that appeared to be the same in 2017 and 2018 (though their dimensions may have changed), there were 2 pools that may have been the same in 2017 and 2018 (these pools were found in the same general locations during both years, but photographs were not taken during the 2017 survey that could be used to verify that they were the same), and there were 60 pools that were newly identified during the 2018 survey. Regarding changes in the extent of the study reach, in 2018, there were only two pools that were identified in the newly surveyed area upstream from cross section 1 . 
A

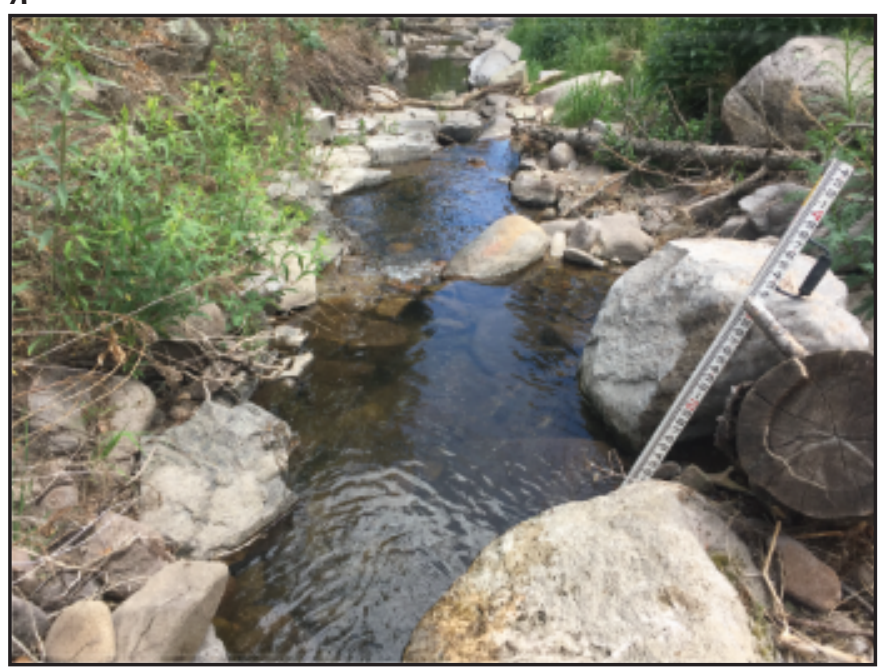

B

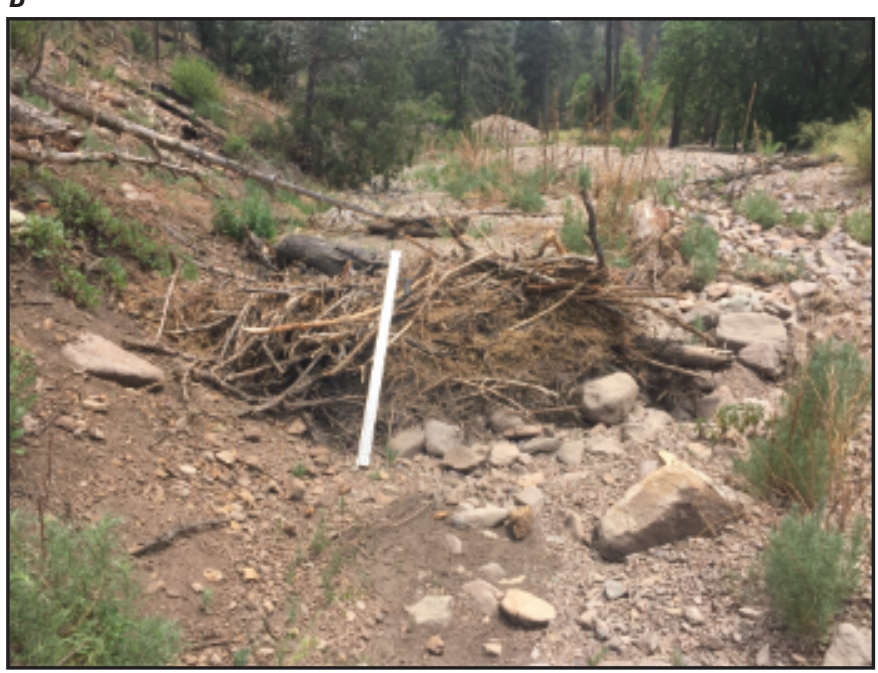

C

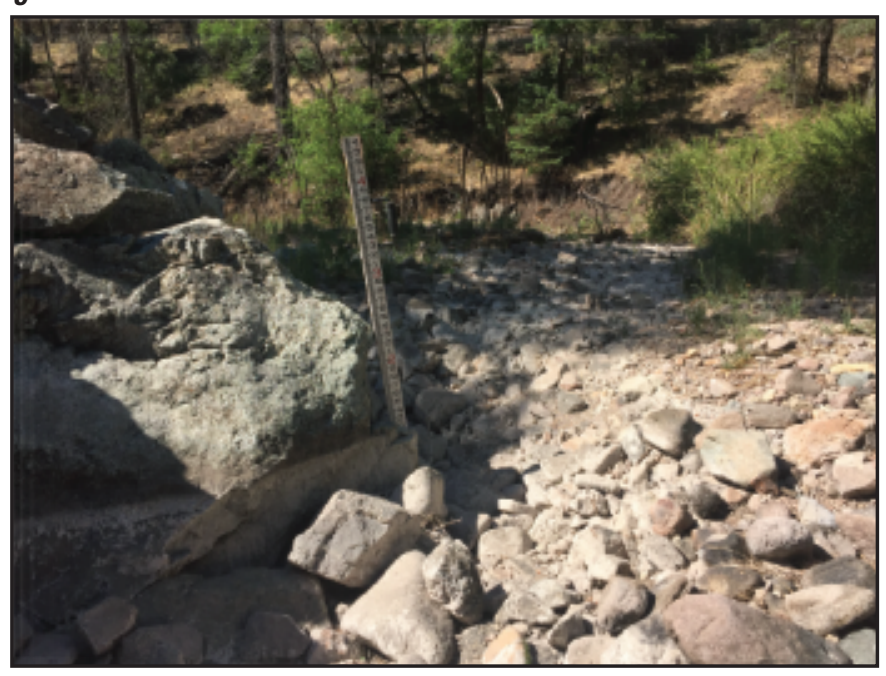

Example photographs presented in figure 10 depict various characteristics of pools identified in the study reach during the 2018 survey (locations of the examples are shown in fig. 8). Figure $10 \mathrm{~A}$ depicts a series of five pools that were located between 30 and $100 \mathrm{ft}$ downstream from cross section 3 during the 2018 survey. Notably, one of the pools is completely hidden behind some boulders, and parts of three woody debris accumulations (two debris deposits and one active debris jam) can also be seen in in the photograph. The pools depicted in figure $10 \mathrm{~A}$ were included in the relatively dense cluster of nine pools that were found in the reach segment that extended from the second road crossing to about $100 \mathrm{ft}$ downstream from cross section 3 . The residual depths of the pools depicted in figure $10 \mathrm{~A}$ ranged from 0.37 to $1.23 \mathrm{ft}$ (Graziano, 2020); therefore, their classifications ranged from shallow to intermediate. One of the pools depicted in the background of figure $10 \mathrm{~A}$ was the only pool where fish were observed during the 2018 survey. Two of the five pools depicted in figure $10 \mathrm{~A}$ were also identified during the 2017 survey, though all five may have been present during the 2017 survey.

Figure $10 B$ depicts a dry pool that was 1 of the 10 pools identified during the 2018 survey that were colocated with active debris jams that may have influenced their formation. The dry pool depicted in figure $10 B$ was found in the middle of a relatively large flood deposit in what appeared to be the main channel of the study reach. The residual depth for the pool depicted in figure $10 B$ was $1.5 \mathrm{ft}$ (Graziano, 2020); therefore, it was classified as deep. Neither the pool nor the colocated active debris jam was identified during the 2017 survey, and the active debris jam was not likely to have been overlooked during the 2017 survey; therefore, the active debris jam likely formed as a result of the high flows that occurred between the 2017 and 2018 surveys and may have influenced the formation of the pool during those same high flows.

Figure 10. Examples of pools found in North Fork Eagle Creek, south-central New Mexico, 2018. All photographs were taken facing downstream. For scale, a survey rod that is 4.46 feet in length (with graduation at feet, tenths of feet, and hundredths of feet) was included in each photograph. Locations of examples are shown in figure 8 . $A$, Series of pools, which were found between 30 and 100 feet downstream from cross section 3 and photographed with parts of nearby woody debris accumulations. $B$, Dry pool, which was colocated with an active debris jam that appears to have influenced the formation of the pool. C, Dry pool, which was classified as deep (residual depth of 2 feet) and was identified during both the 2017 and 2018 surveys. 
Figure $10 C$ depicts one of the three dry pools identified during the 2018 survey that had residual depths of $2 \mathrm{ft}$ (the deepest of the residual depths) (Graziano, 2020). The formation of the dry pool depicted in figure $10 \mathrm{C}$ was likely influenced by the effects of the exposed bedrock (seen protruding from the left bank) on local flow dynamics. During the 2018 survey, it was common to find similar dry pools abutting boulders and exposed bedrock. The dry pool depicted in figure $10 C$ was also found during the 2017 survey, and it was used as an example of a dry pool in Graziano (2019).

\section{Other Features of Geomorphic Significance}

During the 2018 survey, four road crossings, four flood deposits, and two tributary confluences were identified (fig. 4 and fig. 8). Unless major flooding occurs, both the locations and numbers of road crossings and flood deposits are expected to remain the same throughout the planned study period. Additionally, the two identified tributary confluences are expected to remain in the same location throughout the planned study period. However, more tributary confluences may be identified during future surveys because tributary confluence identification was not rigorous and was entirely based either on the presence of water in the tributary or on the presence of engineered structures, such as culverts. During periods when streamflow is higher than it was during the 2018 survey, there are likely other tributaries contributing streamflow to the study reach. Though the identified road crossings, flood deposits, and tributary confluences are all expected to remain in the same locations throughout the planned study period, their locations may become important to understanding the geomorphic processes active during the study period.

During the 2018 survey, four channel bifurcations and seven fine-sediment accumulations were identified. Because these features were not rigorously identified, it is not likely that all of the channel bifurcations and fine-sediment accumulations in the study reach were cataloged. Channel bifurcations in dry sections of the channel, especially those in the larger flood deposits, could be difficult to identify, primarily because there was not always a clear path that streamflow would follow, and in the larger flood deposits, some sections of the channel appeared to be braided and separated into more than two distributaries instead of bifurcated into just two distinct channels. The identification of fine-sediment accumulations was also affected by the local stream characteristics but in different ways. Specifically, fine-sediment accumulations were only observed in dry sections of the study reach and may have been overlooked in both flood deposits and areas where water was present.

Example photographs presented in figure 11 depict various characteristics of channel bifurcations and fine-sediment accumulations identified in the study reach during the 2018 survey (locations of the examples are shown in fig. 8). Figure $11 \mathrm{~A}$ depicts a channel bifurcation that was about $40 \mathrm{ft}$ long (channelwise) and had a debris deposit in it at the point where it forked. Woody debris accumulations were found at all four of the channel bifurcations identified in the study reach. Figure $11 B$ depicts a fine-sediment accumulation that was directly downstream from exposed bedrock that likely influenced its formation. The plants present in this fine-sediment accumulation may have been providing some stability to the accumulation. Figure $11 C$ depicts a fine-sediment accumulation that was directly downstream from an active debris jam that likely influenced its formation. Because the formation of this fine-sediment accumulation was likely influenced by a relatively temporary feature (that is, a woody debris accumulation instead of a boulder or exposed bedrock) and plants were not observed to be growing in the accumulation, this fine-sediment accumulation may not have been as stable or as old as the fine-sediment accumulation depicted in figure $11 B$. Of the seven fine-sediment accumulations identified during the 2018 survey, the formation of four appeared to have been influenced by active debris jams, and the formation of the other three appeared to have been influenced by bedrock or boulders. However, only the fine-sediment accumulation depicted in figure $11 B$ had plants growing in it. 
$\boldsymbol{A}$

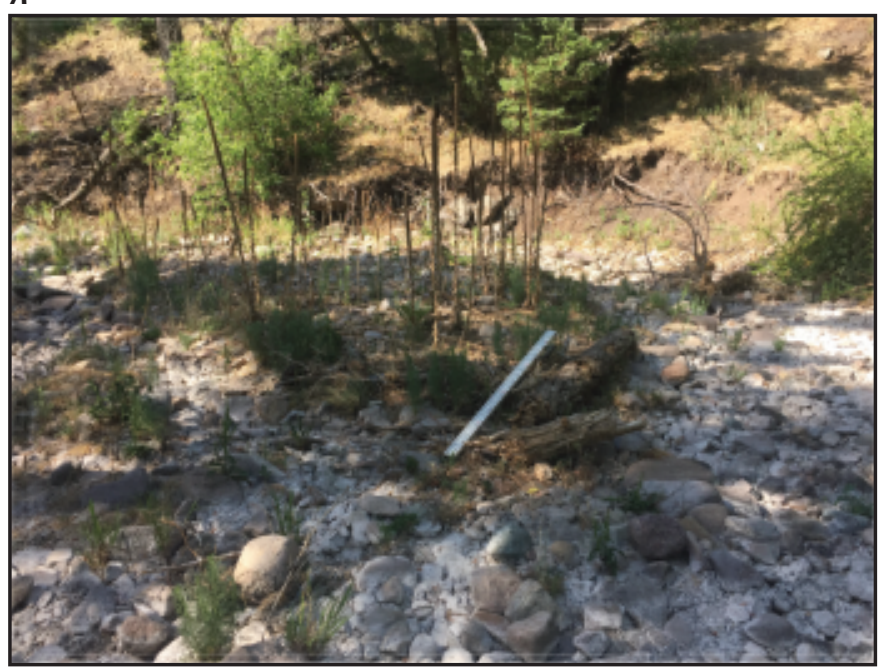

B

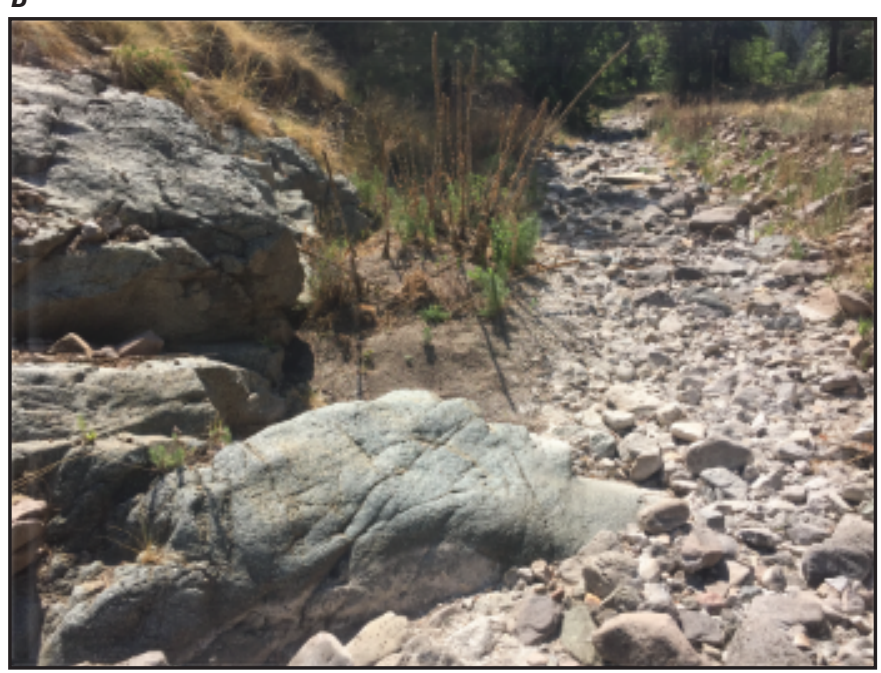

C

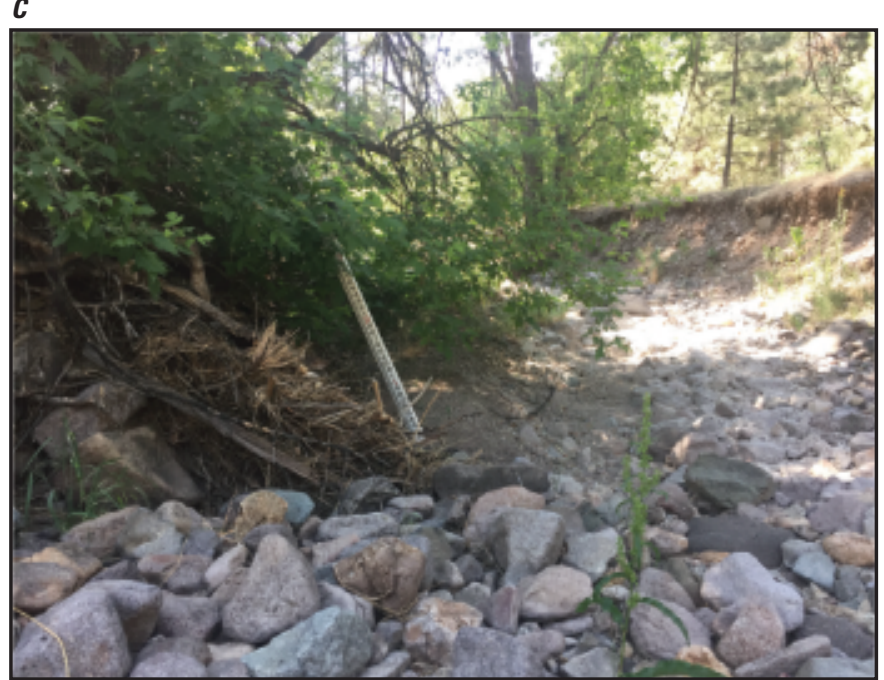

The Geomorphic Implications of the Hydrologic Responses to the $\mathbf{2 0 1 2}$ Little Bear Fire and the Potential for Future Geomorphic Change to North Fork Eagle Creek

The 2012 Little Bear Fire caused substantial loss of vegetation in the North Fork Eagle Creek Basin. The loss of vegetation and other potential fire effects were expected to cause hydrologic responses that included reduced infiltration and increased overland runoff, temporary increases in "flashy" responses to rainfall and snowmelt, increased sediment and debris yields, and changes to vegetation from flooding (USDA Forest Service, 2016). The results from the first two of five planned geomorphic surveys of North Fork Eagle Creek, presented in this report and in Graziano (2019), have been used to assess some of these expected hydrologic responses, monitor geomorphic change to North Fork Eagle Creek, and provide baseline data for future geomorphic monitoring of North Fork Eagle Creek. In this section, these expected hydrologic responses and their geomorphic implications are discussed (with the exception of changes to vegetation from flooding). Further, based on data collected thus far, the hypotheses made in Graziano (2019) about the potential for future geomorphic change to North Fork Eagle Creek are assessed.

In Graziano (2019), the expected hydrologic responses of reduced infiltration, increased overland runoff, and "flashy" responses to rainfall and snowmelt were assessed by using the peak annual streamflow records from the North Fork and Eagle Creek gaging stations. Though only 5 years of data had been collected since the Little Bear Fire (and at the North Fork gaging station, only 5 years of data were collected before the Little Bear Fire), the peak annual streamflow records examined in Graziano (2019) appeared to indicate that these expected hydrologic responses had been occurring.

Figure 11. Examples of channel bifurcations and fine-sediment accumulations found in North Fork Eagle Creek, south-central New Mexico, 2018. All photographs were taken facing downstream. For scale, a survey rod that is 4.46 feet in length (with graduation at feet, tenths of feet, and hundredths of feet) was included in two of the photographs. Locations of examples are shown in figure 8. $A$, Channel bifurcation, which was about 40 feet long and has a debris deposit at the point where it forks. $B$, Fine-sediment accumulation, which was directly downstream from exposed bedrock. $C$, Fine-sediment accumulation, which was directly downstream from an active debris jam. 
Graziano (2019) also found that peak annual streamflows of relatively high magnitude (greater than $50 \mathrm{ft} 3 / \mathrm{s}$ ) had most commonly occurred during the North American monsoon season (both before and after the fire), indicating that most peak annual streamflows had been caused by rainfall rather than snowmelt. Therefore, it was hypothesized in Graziano (2019) that, if observable geomorphic change occurs in the study reach during the 5 years planned for the study, there is a strong possibility it will have been caused by rainfall during the months of the North American monsoon season (July, August, and September). The streamflow records analyzed in this report, from the period between the 2017 and 2018 surveys, partially supported this hypothesis because the "flashiest" high-flow event at the Eagle Creek gaging station (with a peak streamflow greater than $50 \mathrm{ft} 3 / \mathrm{s}$ ) occurred during the North American monsoon season (fig. $5 \mathrm{~A}$ ), and that high-flow event likely made some contributions to the geomorphic changes that occurred in the study reach between the 2017 and 2018 surveys. However, the highest magnitude peak instantaneous streamflow and the longest period of sustained high flows in the study reach (for the period between the 2017 and 2018 surveys) occurred in the month of February (fig. $5 A$ and $B$ ) and had presumably been caused by snowmelt runoff, indicating that streamflow resulting from snowmelt runoff in the winter likely contributed to the geomorphic changes observed in the reach during the 2018 survey as well.

Graziano (2019) suggested that long periods when streamflow remained less than $2 \mathrm{ft} 3 / \mathrm{s}$ in the study reach, prior to the 2017 survey, indicated that it was possible that neither rainfall nor snowmelt would be substantial enough to cause observable geomorphic change in the study reach over the course of the study period. However, streamflows much greater than $2 \mathrm{ft} 3 / \mathrm{s}$ did occur in the study reach after the 2017 survey, and they did appear to have caused some observable geomorphic change in the study reach. Though, if there are future periods of 1 year or longer where streamflow remains less than $2 \mathrm{ft}^{3} / \mathrm{s}$ in the study reach, it is still possible that there could be periods of 1 year or longer when no additional geomorphic changes are observed.

Limited annual monitoring of increases in sediment and debris yields (which were also expected hydrologic responses to the 2012 Little Bear Fire) began with the 2017 geomorphic survey of North Fork Eagle Creek and continued with the 2018 geomorphic survey of North Fork Eagle Creek. From 2017 to 2018, sediment yields were monitored through repeat surveys of select cross sections of the study reach of North Fork Eagle Creek. Physical changes were only measured in 3 of the 14 cross sections that were surveyed in both years, and the most substantial changes appeared to have been caused by erosion and degradation. Therefore, evidence for substantial sediment accumulation in the study reach (which is a possible result of increased sediment yields) was not found to have occurred between the two surveys. However, because there have been many limitations to the postwildfire sediment yield monitoring efforts, it cannot be concluded that sediment yields did not increase or continue to be higher than normal as a result of the fire. Sediment yield monitoring efforts have included the limitations that sediment accumulation outside of the 14 cross-section locations has not been monitored (and was only minimally surveyed in 2018), that sediment transport has not been monitored, and that monitoring of sediment accumulation only began 5 years after the fire.

From 2017 to 2018, debris yields were limitedly monitored through the surveying of woody debris accumulations in the channel of the study reach. It was found that high flows that occurred between the 2017 and 2018 surveys were able to mobilize woody debris in the channel, and though some woody debris accumulations identified in 2018 may have been overlooked in 2017, the total number of woody debris accumulations in the channel appeared to increase between the two surveys. In both 2017 and 2018, some woody debris was found that had been burn marked or charred. This may be an indication that some of the woody debris in the channel was sourced from trees or forest litter that had burned during 2012 Little Bear Fire. In 2018, it was also found that some woody debris accumulations may have influenced geomorphic change in the study reach. For example, active debris jams may have influenced the changes to cross section 4 , the formation of 10 of the pools identified in 2018, and the formation of 4 of the fine-sediment accumulations identified in 2018. However, most woody debris accumulations identified in 2018 did not appear to have substantially influenced geomorphic change in the locations where they were found. Further, at the typical streamflow rates of less than $2 \mathrm{ft} 3 / \mathrm{s}$ (U.S. Geological Survey 2019a, b), which were observed during the surveys, flow direction and velocity have not appeared to be substantially affected by woody debris. Generally, at those flow rates, it is likely that either the channel has been dry at locations containing woody debris or the flow has been low enough to simply trickle through the woody debris.

On the basis of the locations of the active debris jams found in 2017, Graziano (2019) hypothesized that, if woody-debris-influenced geomorphic change is to occur during the study period, it will be more likely to occur in the uppermost or lowermost portions of the study reach than in the center portion of the study reach. This hypothesis was only partially supported by the results of the 2018 survey. Qualitative observations from the 2018 survey appeared to indicate that active debris jams do have more influence on geomorphic change than debris deposits or potential debris jams do, but the results from both surveys have indicated that the distribution of active debris jams found during one survey can change substantially after only one or two high-flow events. Specifically, though most active debris jams identified in 2017 were found in the uppermost and lowermost portions of the study reach, active debris jams formed in the center portion of the study reach between the 2017 and 2018 surveys, and some of those active debris jams also appeared to have influenced geomorphic change. 
In Graziano (2019), it was hypothesized that, because most woody debris accumulations surveyed in 2017 were not both large and well anchored, it was likely that most of the woody debris surveyed in 2017 would be transported downstream and out of the study reach during a high-flow event, rather than becoming or remaining jammed where it can cause substantial geomorphic change. This hypothesis seemed to be supported by the results of the 2018 survey because more than half of the woody debris accumulations surveyed in 2017 were no longer present during the 2018 survey and because the woody debris accumulations that did remain in place were primarily large and well-anchored active and potential debris jams. Notably, most of the woody debris accumulations surveyed in 2018 were also not both large and well anchored.

A final hypothesis about the geomorphic implications of woody debris from Graziano (2019) was that, if moderate streamflows are sustained (such as in a period of sustained snowmelt runoff), the streamflow levels may not be high enough to carry away some of the larger active debris jams but could still be high enough to result in small, local effects on channel dimensions (such as bed scour, bed fill, and bank erosion). The results of the 2018 survey seemed to partially support this hypothesis because there was a period of sustained snowmelt runoff between the 2017 and 2018 surveys and some small, local effects on channel dimensions were observed where active debris jams had remained in place, but those effects may have resulted from either the moderate sustained flows or the high flows that occurred during the period.

During the 2017 geomorphic survey, 14 pools were found in the study reach (Graziano, 2019), and during the 2018 geomorphic survey, 71 pools were found in the study reach (using methods significantly refined from those used during the 2017 survey). In Graziano (2019), it was hypothesized that the identified pools would likely remain in place, with the same general size and structure, unless flow events of a particularly high magnitude occurred. Further, Graziano (2019) hypothesized that, because much of the study reach was dry during the 2017 geomorphic survey, it would be possible for new pools to be identified in future years (even if geomorphic change had not occurred). These hypotheses were generally supported by the results of the 2018 survey, except there was not enough evidence to support the hypothesis that the pools maintained the same general size and structure (because pools were not measured by any metric in 2017, and some pools identified in 2017 were not photographed). Though high flows did occur, only 5 of the 14 pools identified in 2017 no longer appeared to be present in 2018 , indicating that most of the pools identified in 2017 had remained in place. Also, because the methods for identifying and measuring pools were refined in 2018, a substantially higher number of pools were identified in the study reach during the 2018 survey (many of which were found in dry sections). Plans for future surveys of the study reach include continued use of those pool identification and measurement methods that were refined for the 2018 survey; therefore, it is expected to be much less likely for new pools to be identified during future surveys (in wet or dry sections of the study reach) unless they newly form during the remaining years of the study.

\section{Conclusion}

The 2012 Little Bear Fire resulted in substantial loss of vegetation in the Eagle Creek Basin. The loss of vegetation has been expected to cause a variety of hydrologic responses that could influence geomorphic change to North Fork Eagle Creek (a stream of hydrologic significance in the Eagle Creek Basin). To monitor short-term geomorphic change to North Fork Eagle Creek, geomorphic surveys of a downstream study reach of North Fork Eagle Creek were conducted in June 2017 and June 2018. The geomorphic surveys included surveys of select cross sections and surveys of all woody debris accumulations and pools found in the channel of the study reach. Between the 2017 and 2018 geomorphic surveys, high-flow events resulting from both rainfall (during the North American monsoon season) and snowmelt runoff (during the winter) occurred in the study reach. Those high-flow events appeared to have caused some minor and localized geomorphic changes in the study reach, which were evaluated through comparison of the 2017 and 2018 survey results.

Comparisons of the cross-section survey results indicated that minor observable geomorphic changes had occurred in 3 of the 14 cross sections surveyed in 2017 and 2018. These minor observable geomorphic changes included aggradation or degradation of surface materials by about $1-2 \mathrm{ft}$ in some parts of the affected cross sections. During the 2018 geomorphic survey, 112 distinct accumulations of woody debris and 71 pools were identified in the study reach. Only 22 of the 112 woody debris accumulations identified during the 2018 survey were certain to have also been present during the 2017 survey (when 58 woody debris accumulations were identified), indicating that most of the woody debris accumulations surveyed in 2017 were likely transported during the high-flow events between the 2017 and 2018 surveys but also indicating that the flows during those events were not high enough to remove some of the more firmly anchored woody debris accumulations. Most woody debris accumulations identified in 2018 did not appear to have substantially influenced geomorphic change in the locations where they were found. However, the formation of 10 of the 71 pools identified in the study reach in 2018 appeared to have been influenced by the presence of woody debris, indicating that some woody debris accumulations may have driven local geomorphic changes.

Because the study began 5 years after the 2012 Little Bear Fire and because the period and geomorphic scope of the study have so far been limited, it cannot be said that the geomorphic changes observed between the 2017 and 2018 surveys are representative of a pattern of geomorphic change following the 2012 Little Bear Fire. Though, once geomorphic changes between the 2017 and 2018 surveys can be compared 
with results from geomorphic surveys planned for 2019, 2020, and 2021, it may be possible to develop an understanding of the patterns in geomorphic change following the 2012 Little Bear Fire.

\section{Acknowledgments}

Matthew Pedroza, USGS, assisted with the field work.

\section{References Cited}

Abbe, T.B., and Montgomery, D.R., 1996, Large woody debris jams, channel hydraulics and habitat formation in large rivers: Regulated Rivers: Research and Management, v. 12, no. 2-3, p. 201-221, accessed April 19, 2018, at https://doi.org/10.1002/(SICI)1099-1646(199603)12:2/3<20 $1::$ AID-RRR390>3.0.CO;2-A.

Benson, M.A., and Dalrymple, T., 1967, General field and office procedures for indirect measurements: U.S. Geological Survey Techniques of Water-Resources Investigations, book 3, chap. Al, 30 p., accessed August 8, 2018, at https://doi.org/10.3133/twri03A1.

Bradley, D.N., 2012, Slope-area computation program graphical user interface 1.0 - A preprocessing and post processing tool for estimating peak flood discharge using the slope-area method: U.S. Geological Survey Fact Sheet 2012-3112, 4 p., accessed July 26, 2018, at https://pubs.usgs.gov/fs/2012/3112.

Buffington, J.M., Lisle, T.E., Woodsmith, R.D., and Hilton, S., 2002, Controls on the size and occurrence of pools in coarse-grained forest rivers: River Research and Applications, v. 18, no. 6, p. 507-531, accessed May 4, 2018, at https://doi.org/10.1002/rra.693.

Dalrymple, T., and Benson, M.A., 1967, Measurement of peak discharge by the slope-area method: U.S. Geological Survey Techniques of Water-Resources Investigations, book 3, chap. A2, 12 p., accessed August 8, 2018, at https://doi.org/ 10.3133/twri03A2.

Fulford, J.M., 1994, User's guide to SAC, a computer program for computing discharge by slope-area method: U.S. Geological Survey Open-File Report 94-360, 31 p., accessed July 26, 2018, at https://doi.org/10.3133/ofr94360.

Graziano, A.P., 2018, Data supporting the 2017 geomorphic survey of North Fork Eagle Creek, New Mexico: U.S. Geological Survey data release, accessed August 29, 2019, at https://doi.org/10.5066/F7PR7TX3.
Graziano, A.P., 2019, Geomorphic survey of North Fork Eagle Creek, New Mexico, 2017: U.S. Geological Survey Open-File Report 2018-1187, 28 p., https://doi.org/10.3133/ ofr20181187.

Graziano, A.P., 2020, Data supporting the 2018 geomorphic survey of North Fork Eagle Creek, New Mexico: U.S. Geological Survey data release, https://doi.org/10.5066/ P94ZQHKU.

Gurnell, A.M., Piegay, H., Swanson, F.J., and Gregory, S.V., 2002, Large wood and fluvial processes: Freshwater Biology, v. 47, no. 4, p. 601-619, accessed April 21, 2020, at https://doi.org/10.1046/j.1365-2427.2002.00916.x.

Heimann, D.C., 2017, Assessment of an in-channel redistribution technique for large woody debris management in Locust Creek, Linn County, Missouri: U.S. Geological Survey Scientific Investigations Report 2017-5120, 25 p., accessed April 19, 2018, at https://doi.org/10.3133/ $\operatorname{sir} 20175120$.

Johnson, P.A., and Heil, T.M., 1996, Uncertainty in estimating bankfull conditions: Journal of the American Water Resources Association, v. 32, no. 6, p. 1283-1291, accessed July 26, 2018, at https://doi.org/10.1111/j.17521688.1996.tb03497.x.

Knighton, D.A., 1998, Fluvial forms and processes-A new perspective: London, Arnold, 383 p.

Leopold, L.B., Wolman, M.G., and Miller, J.P., 1964, Fluvial processes in geomorphology: San Francisco, W.H. Freeman, 522 p.

Lisle, T.E., 1982, Effects of aggradation and degradation on riffle pool morphology in natural gravel channels, northwestern California: Water Resources Research, v. 18, no. 6, p. 1643-1651, accessed August 8, 2018, at https://doi.org/10.1029/WR018i006p01643.

Lisle, T.E., 1987, Using "residual depths" to monitor pool depths independently of discharge: Berkeley, Calif., U.S. Department of Agriculture, Pacific Southwest Forest and Range Experiment Station Research Note PSW-394, 4 p., accessed April 19, 2018, at https://doi.org/10.2737/PSWRN-394.

Madej, M.A., and Ozaki, V., 1996, Channel response to sediment wave propagation and movement, Redwood Creek, California, USA: Earth Surface Processes and Landforms, v. 21, no. 10, p. 911-927, accessed May 4, 2018, at https://doi.org/10.1002/(SICI)1096-9837(199610)21:10<91 $1:: A I D-E S P 621>3.0 . C O ; 2-1$. 
Matherne, A.M., Myers, N.C., and McCoy, K.J., 2010, Hydrology of Eagle Creek Basin and effects of groundwater pumping on discharge, 1969-2009: U.S. Geological Survey Scientific Investigations Report 2010-5205, 73 p., accessed August 25, 2017, at https://doi.org/10.3133/sir2010520. [Revised November 2011.]

Montgomery, D.R., Buffington, J.M., Smith, R., Schmidt, K., and Pess, G., 1995, Pool spacing in forest channels: Water Resources Research, v. 31, no. 4, p. 1097-1105, accessed August 8, 2018, at https://doi.org/10.1029/ 94WR03285.

Nakamura, F., and Swanson, F.J., 1993, Effects of coarse woody debris on morphology and sediment storage of a mountain stream system in western Oregon: Earth Surface Processes and Landforms, v. 18, no. 1, p. 43-61, accessed May 2, 2018, at https://doi.org/10.1002/ esp.3290180104.

Rydlund, P.H., Jr., and Densmore, B.K., 2012, Methods of practice and guidelines for using survey-grade global navigation satellite systems (GNSS) to establish vertical datum in the United States Geological Survey: U.S. Geological Survey Techniques and Methods, book 11, chap. D1, 102 p. with appendixes, accessed September 7, 2017, at https://doi.org/10.3133/tm11D1.

U.S. Department of Agriculture [USDA] Forest Service, 2015, Final environmental impact statement, North Fork Eagle Creek Wells Special Use Authorization: U.S. Department of Agriculture Forest Service, 574 p, accessed April 19, 2018, at https://www.fs.usda.gov/project/? project $=9603$.

U.S. Department of Agriculture [USDA] Forest Service, 2016, Record of decision, North Fork Eagle Creek Wells Special Use Authorization: U.S. Department of Agriculture Forest Service, 28 p., accessed July 18, 2018, at https://www.fs.usda.gov/project/?project=9603.
U.S. Department of Agriculture [USDA] Forest Service, Little Bear Fire Burned Area Emergency Response [BAER] Team, 2012, Little Bear Fire burn severity derived from June 18, 2012, Burned Area Reflectance Classifications [BARC]: U.S. Department of Agriculture Forest Service, accessed March 27, 2020, at https://fsapps.nwcg.gov/afm/ baer/download.php?year=2012.

U.S. Geological Survey, 2019a, USGS 08387600 Eagle Creek below South Fork near Alto, NM, in USGS water data for the Nation: U.S. Geological Survey National Water Information System database, accessed June 4, 2019, at https://doi.org/10.5066/F7P55KJN. [Site information directly accessible at https://waterdata.usgs.gov/nm/nwis/ inventory/?site_no $=08387600$.]

U.S. Geological Survey, 2019b, USGS 08387550 North Fork Eagle Creek near Alto, NM, in USGS water data for the Nation: U.S. Geological Survey National Water Information System database, accessed June 5, 2019, at https://doi.org/ 10.5066/F7P55KJN. [Site information directly accessible at https://waterdata.usgs.gov/nm/nwis/inventory/?site_no= 08387550.]

U.S. Geological Survey, 2019c, USGS 08387575 South Fork Eagle Creek near Alto, NM, in USGS water data for the Nation: U.S. Geological Survey National Water Information System database, accessed June 6, 2019, at https://doi.org/ 10.5066/F7P55KJN. [Site information directly accessible at https://waterdata.usgs.gov/nm/nwis/inventory/?site_no= 08387575.]

Wallace, J.B., Webster, J.R., and Meyer, J.L., 1995, Influence of $\log$ additions on physical and biotic characteristics of a mountain stream: Canadian Journal of Fisheries and Aquatic Sciences, v. 52, no. 10, p. 2120-2137, accessed May 4, 2018, at https://doi.org/10.1139/f95-805.

\author{
For more information about this publication, contact \\ Director, New Mexico Water Science Center \\ U.S. Geological Survey \\ 6700 Edith Blvd. NE \\ Albuquerque, NM 87113 \\ For additional information visit \\ https://www.usgs.gov/centers/nm-water \\ Publishing support provided by \\ Lafayette Publishing Service Center
}





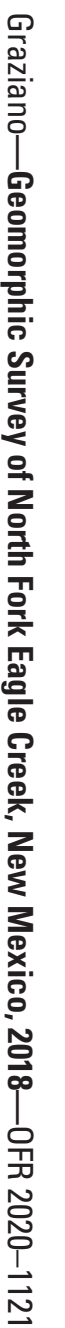

